of $x$.

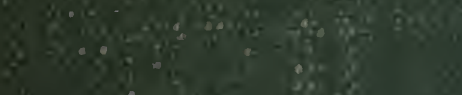

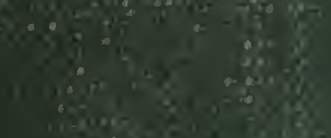

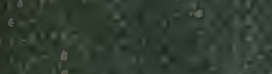

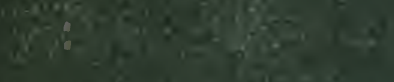

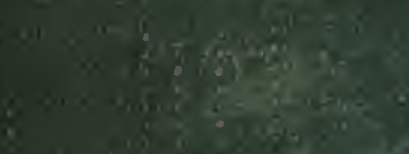

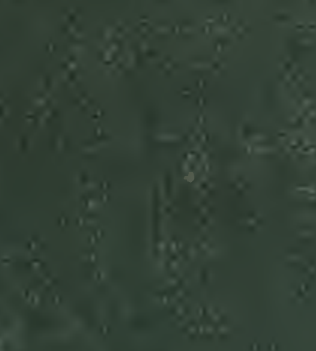

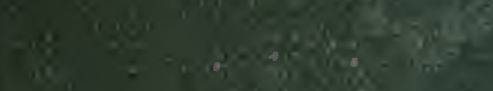

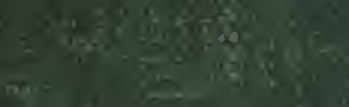

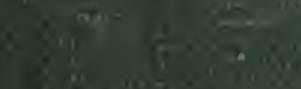

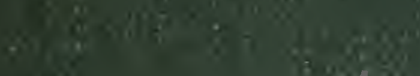

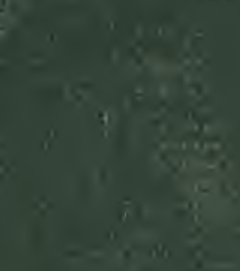

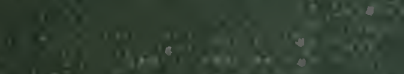

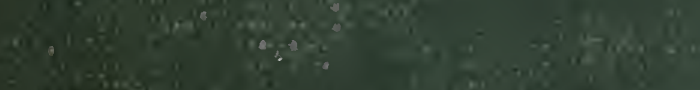

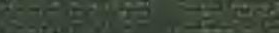

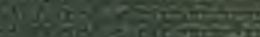

$\tan \frac{1}{2}$

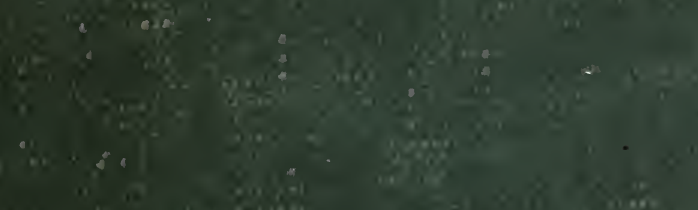

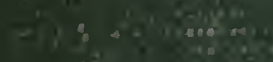

4.

(6)

$2: 2$

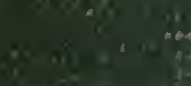

$960^{2}, 82$

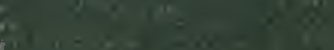

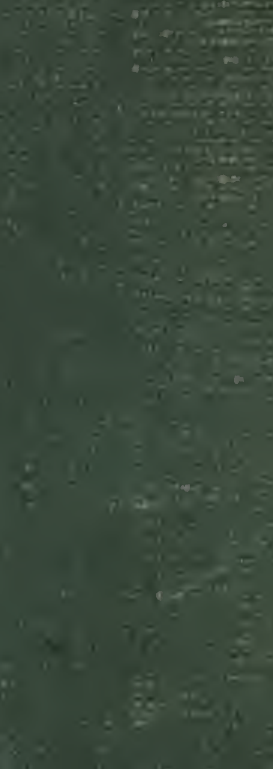



Historic, archived document

Do not assume content reflects current scientific knowledge, policies, or practices. 


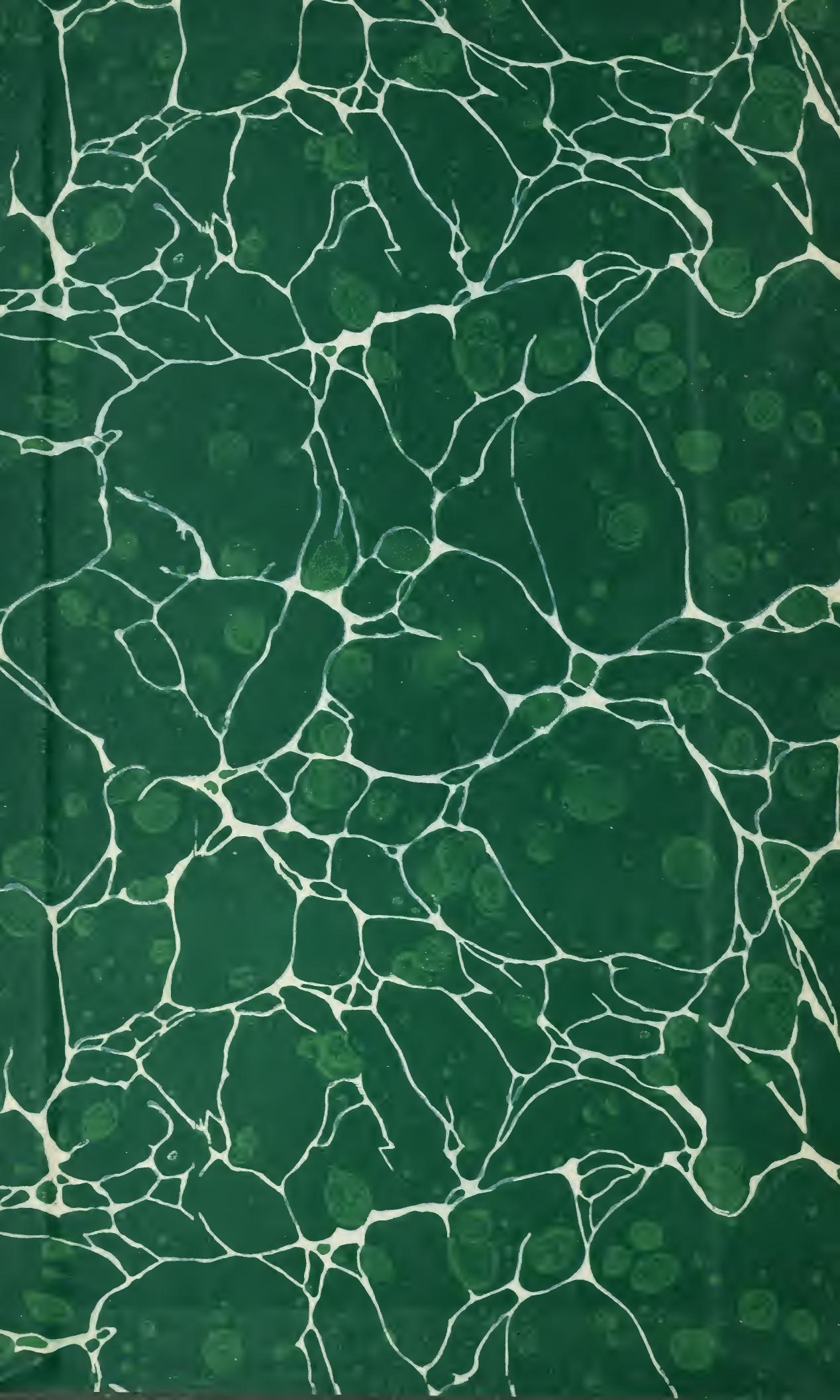




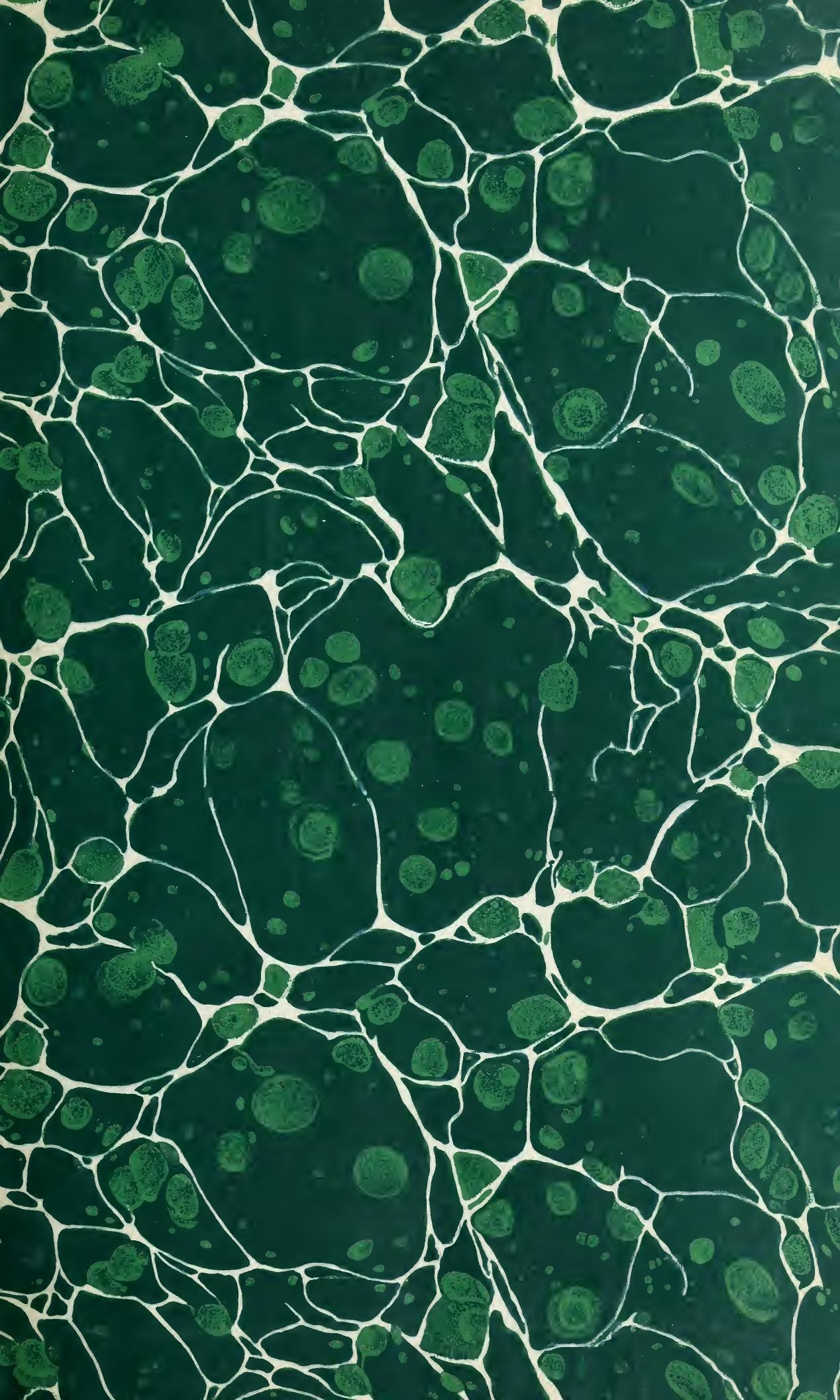








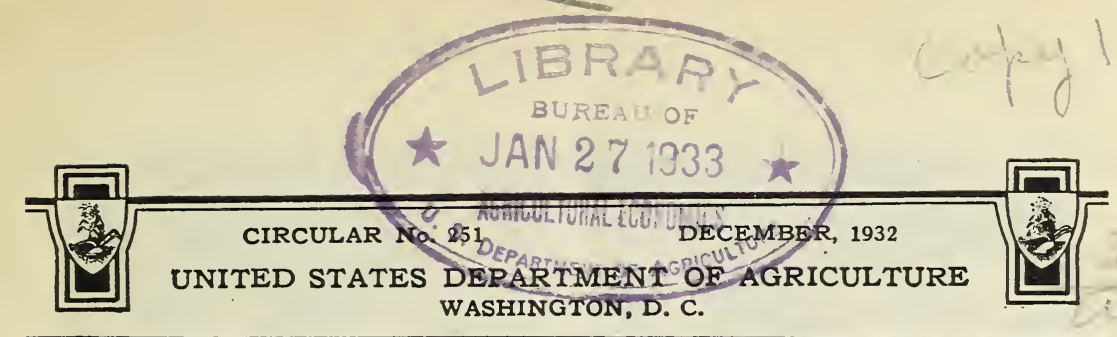

\title{
MUSHROOM GROWING IN THE UNITED STATES
}

\author{
By Edmund B. Lambert, Associate Pathologist, Division of Mycology and \\ Disease Survey, Bureau of Plant Industry ${ }^{2}$
}

\section{CONTENTS}

The cultivated mushroom

Development of the industry

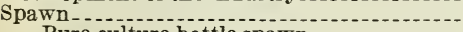
Pure-culture bottle spawn

Varieties

Structures for raising mushrooms House construction. Cultural practice

Preparation of a suitable compost .......

Manure substitutes and supplements.-.Spawning and casing.

\begin{tabular}{r|} 
Page \\
1 \\
3 \\
3 \\
4 \\
7 \\
8 \\
9 \\
10 \\
11 \\
15 \\
18
\end{tabular}

Page

Cultural practice-Continued. Growing conditions Sanitation and disinfection............. 22 Diseases............. 23 Bubbles Bacterial spot.............. 25 Other diseases...................................... 25 Insect pests Prevention and control Harvesting, packing, and marketing.-.....- 28 Costs and returns. . . . . .

\section{THE CULTIVATED MUSHROOM}

The common cultivated mushroom, Agaricus campestris L., is the only species cultivated in the United States, and the majority of the mushrooms consumed are of this one general type. In the European and oriental markets several other kinds of fleshy fungi are sold. The cèpes and truffles of Europe, the kámes of North Africa, and the shii-take and matsu-take of the Orient are examples. A few of these reach our country as dried or canned products, but no systematic attempt to introduce their cultivation has been made.

The mushroom is a member of a large group of plants known as fungi. The natural life cycle of the cultivated mushroom begins with the germination of the spore, which gives rise to a threadlike growth called mycelium. This mycelium seeks, absorbs, and transports food, and usually grows extensively underground (fig. 1) before appearing on the surface to produce the mushroom of commerce. The mushroom completes the life cycle by producing and liberating spores, which are found on the gills radiating from the stem on the under side of the cap. (Fig. 2.) Thus there are three distinct phases

1 This circular is based on survers of commercial practice in Pennsylvania, New York, Ohio, Illinois, and Minnesota in 1928, 1929, and 1930, and experiments on cultural practice, artificial manure, and disease control in the experimental mushroom house at the Arlington Experiment Farm, Rosslyn, Va. The section on costs and returns is based on the records of several sucesssful growers in eastern Pennsylvania. The graphs of New York prices are based on quotations in The Producers Price Current. The writer is: especially grateful to several commercial growers and spawn makers in eastern Pennsylvania for their friendly cooperation.

$$
142654^{\circ}-32-1
$$




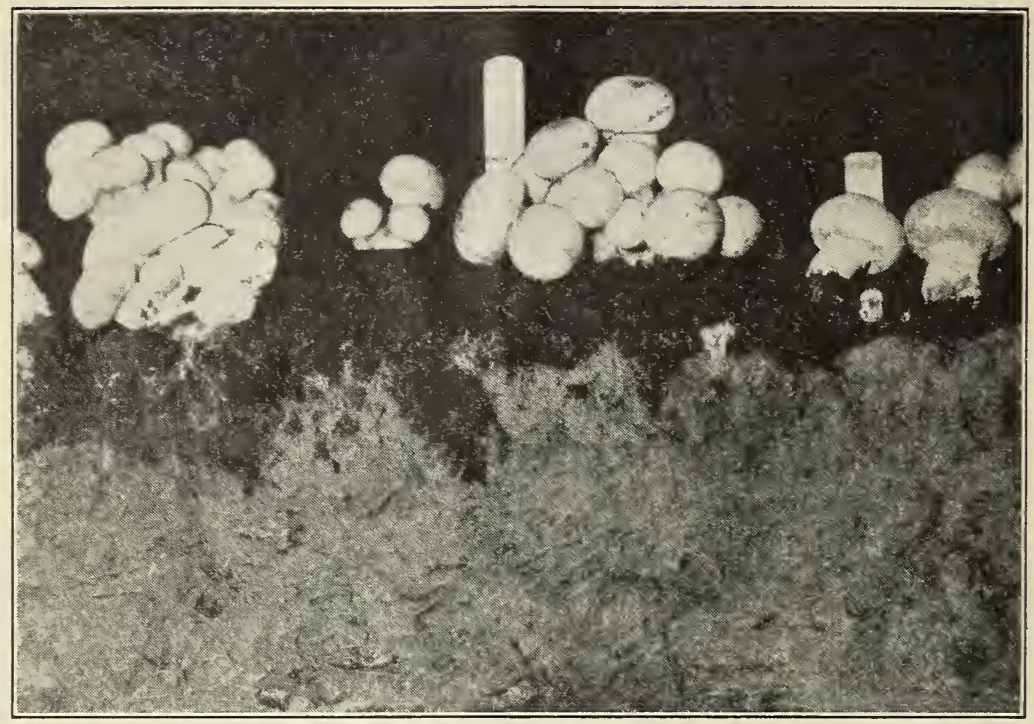

FIGURE 1.-Cross section of a mushroom bed. Note the mycelium in the compost covered with a layer of soil, and the mushrooms above

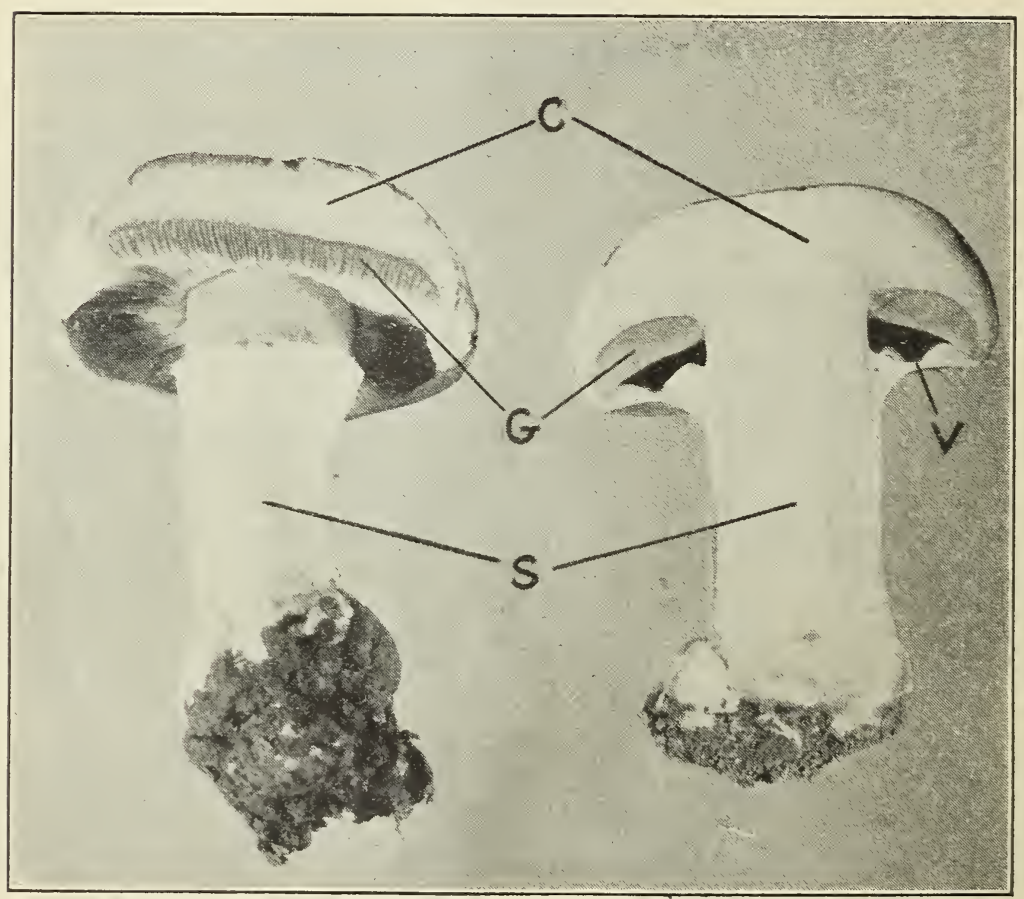

FIGURE 2.-Mushroom structure: C, Cap; G, gills ; S, stem; V, veil 
in the growth of the mushroom plant, namely, the germination of the spores, the development of the mycelium underground, and the growth of the fruiting body or mushroom above the ground.

\section{DEVELOPMENT OF THE INDUSTRY}

The practice of cultivating the common mushroom originated in France in the latter part of the seventeenth century, but it was not until toward the end of the nineteenth century that it began to gain a foothold in the United States. At first mushrooms were grown as a side line to market gardening, but as the market developed specialization began.

Although at first abandoned limestone quarries, mines, and sandstone caves were used, the structure that eventually found most favor in this country was the specially constructed mushroom house filled with tiers of shelf beds. On the average, better crops are obtained in these houses than in caves, because favorable conditions

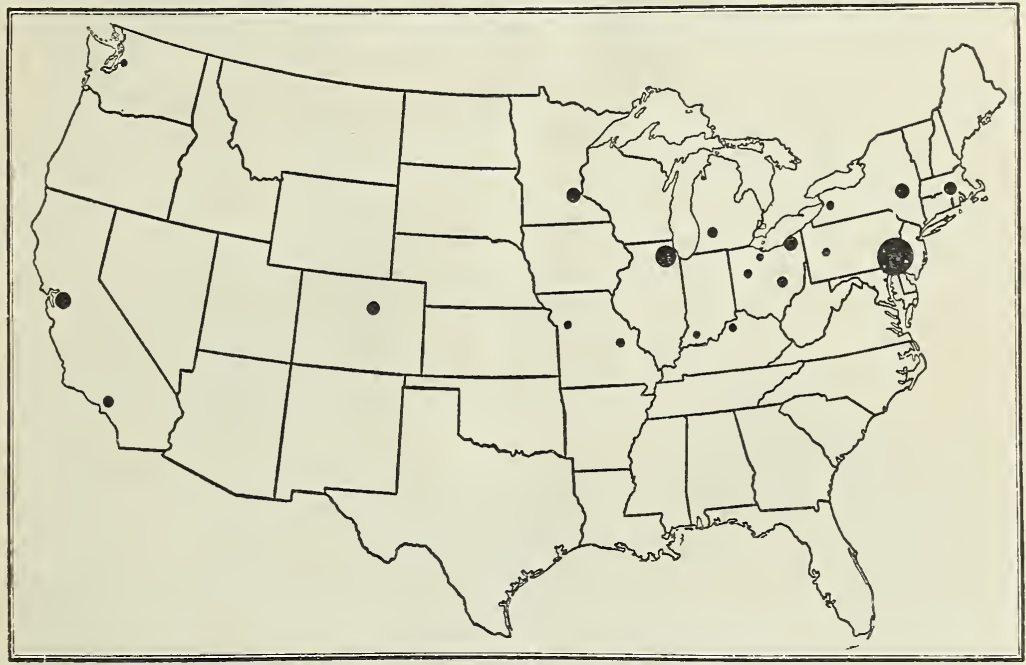

Figure 3.-Map showing (by dots) the approximate distribution of the mushroom industry in the United States

can be more readily obtained and diseases and insect pests are more easily controlled.

As a result of the widespread use of these special houses and the derelopment of better methods of making spawn, the industry has made rapid strides in the last 30 years and at present $15,000,000$ to $20,000,000$ pounds of mushrooms are produced annually. About three-fourths of the industry is located in eastern Pennsylvania and northern Delaware, near the ready markets for mushrooms and supplies of manure in New York City and Philadelphia, but there are also important centers in other States. (Fig. 3.)

\section{SPAWN}

Since the beginning of mushroom culture growers have planted their beds with a specially prepared material filled with living mush- 
room mycelium called spawn. In the early days of mushroom growing the spawn was made from mycelium found growing naturally in the fields or in the caked horse manure of the mill tracks. The spawn maker planted this mycelium in special beds which were later broken up and sold to the growers. This type of spawn was called French-flake spawn. The original wild mycelium used to inoculate these beds was called rirgin spawn or mill-track spawn. Spawn made according to this method was loose and easily injured by excessire heat and drying out. An improrement derised in England early in the nineteenth century consisted of allowing the mycelium from the bits of virgin or mill-track spawn to grow into compressed bricks made of a mixture of horse manure, cow manure, and partly rotted leaves. This product, known as English brick spawn, was superior to French-flake spawn in keeping and shipping qualities. But with both types of spawn it was difficult to maintain pure rarieties, and often fungus diseases and insect pests were distributed with the spawn.

Spawn was first made from pure cultures in France shortly before 1900 and in the United States a few years later. In France spawn was grown from germinated spores while in the United States the mycelium was obtained by the simpler tissue-culture method, which consisted of sowing in bottles of sterile manure bits of mushroom tissue extracted under aseptic conditions from the caps of young mushrooms. After the original spawn was obtained in pure culture by these methods it was used in the place of the virgin spawn to inoculate the bricks. These methods enabled the spawn maker to sell spawn of known varieties and to start cultures comparatively free from disease. But the spawn sold to the grower was not a pure culture and there was still an opportunity for diseases and insect pests to accumulate during the incubation of the bricks and to be distributed with the bricks.

About 14 years ago the most successful spawn makers in the United States abandoned the tissue-culture method for the spore-culture method and a few years later began selling, direct to mushroom growers, quart bottles of pure-culture spawn of the type formerly used to inoculate bricks. Spawn of this kind has the obvious advantage over the old brick spawn of being free from harmful fungi and insects. At the present time nearly all the spawn used in the United States is bottle spawn grown from germinated spores. (Fig. 4.) It gives the grower a practical approximation of pure-culture spawn, pedigreed and free from diseases and insect pests, the only disadvantage being the comparatively poor keeping quality.

\section{PURE-CULTURE BOTTLE SPAWN}

The methods used in manufacturing bottle spawn are adaptations of ordinary pure-culture laboratory technic to large-scale production. The principal operations are the collection of spores, the germination of spores, and the preparation, transferring, and incubation of spawn bottles.

In order to obtain pure cultures, mushroom spores are collected and grown under aseptic conditions. Methods of obtaining a pure collection of spores are baserl on the fact that the young gills of disease-free mushrooms develop under approximately aseptic con- 
ditions in filtered air before the veil is broken, and the mushroom will continue to expand and produce spores even after it has been surface sterilized, peeled, or cut up. Different procedures may be followed to prevent spores of molds on the surface of the mushroom from contaminating the cultures. Stems may be removed and the surface layer peeled off with sterile forceps; the mushroom may be surface sterilized by flaming it or soaking it in a disinfectant; or

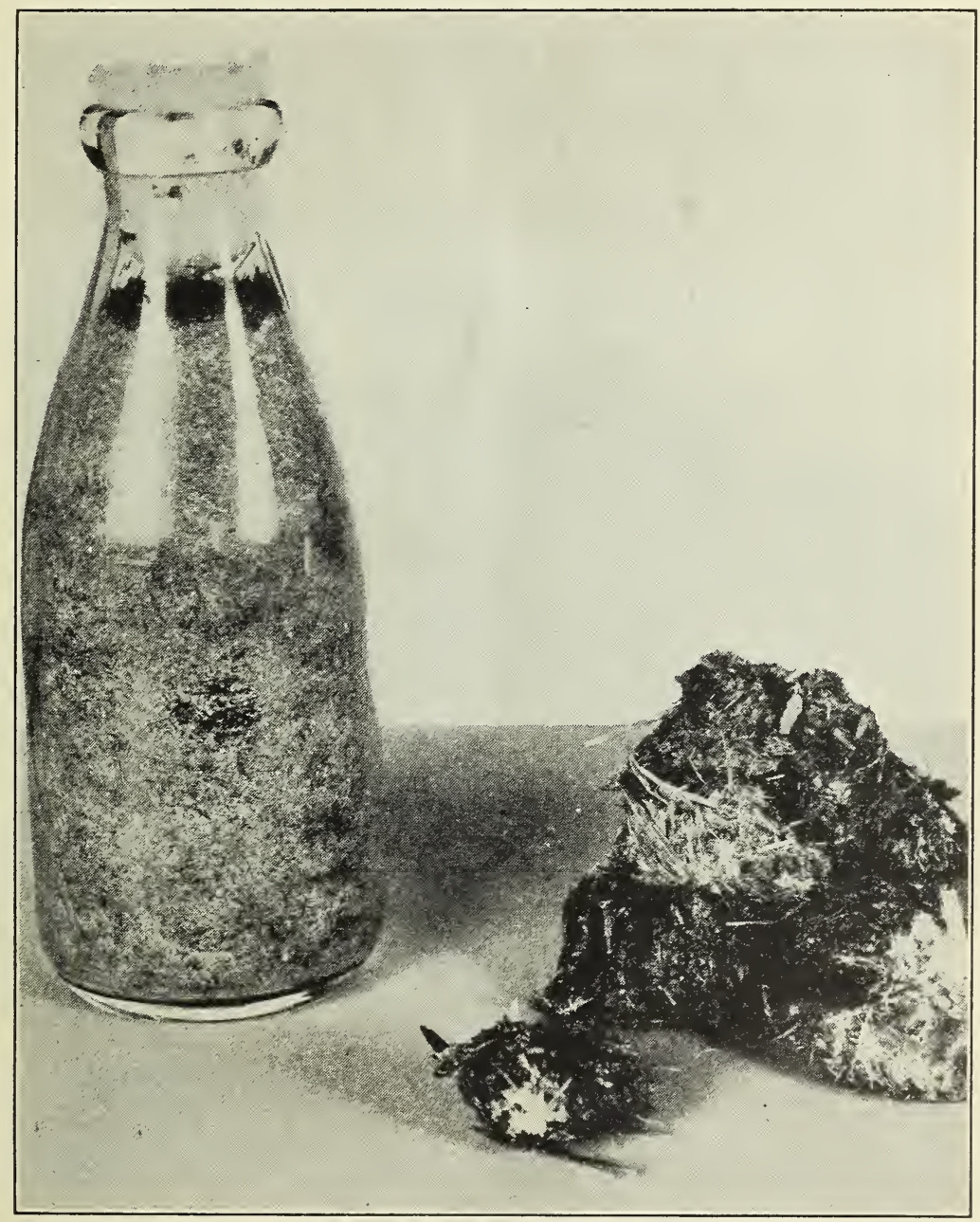

FigURe 4.-Mushroom bottle spawn

the spores may be transferred directly from the gills, or from spore "prints" made by suspending the treated mushroom over a sterile surface in a sterile container.

The spores are transferred for germination either directly to sterile washed compost or first to agar media to make certain that the culture is free from contaminating molds and bacteria. Ordinary potato-dextrose agar and beer-wort agar are suitable media. If the 
culture is pure it will be at least four days to two weeks before any growth appears even at a farorable temperature, $75^{\circ} \mathrm{F}$. When agar is used the mycelium is usually allowed to make a good growth on the agar before it is transferred to spawn bottles.

The material most generally used for filling spawn bottles is manure, short in straw and composted longer than for use in beds, screened and partly dried. This material is tamped firmly into imperial-quart milk bottles and a hole is bored through the center for ventilation. The bottles are then plugged with cotton and steam sterilized. At a temperature of $70^{\circ}$ to $80^{\circ} \mathrm{F}$. the mycelium usually runs through the sterile manure in about 30 days. The spawn from these bottles is used to inoculate compost in other bottles similarly prepared. As a rule, repeated transferring is limited to three generations from the original cultures to aroid socalled running out and the danger of accumulating contamination.

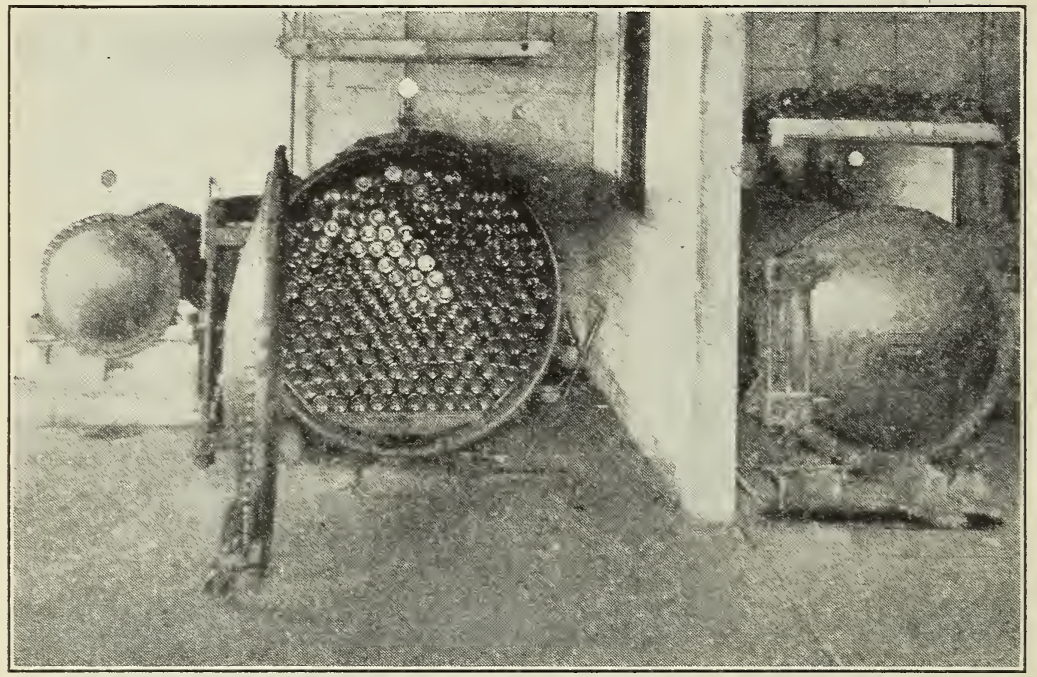

Figure 5.-Autoclaves used for sterilizing spawn bottles

Bottles newly "run" with mycelium are suitable for immediate use in planting beds. If not used immediately they are usually kept in cold storage.

The following special equipment is necessary for successful spawn making: A microscope to discover the nature of contaminating molds; a small autoclave for the preliminary culture work; one or more large canner's' retorts (fig. 5) for sterilization; and apparatus for measuring the reaction of media and manure. In addition, most spawn makers use laundry centrifuges to dry their manure and special motor-driven cutters to shred it. (Fig. 6.) This apparatus and machinery must be housed, special inoculating and incubating rooms are necessary, and cold-storage facilities must be provided for storing spawn. The establishments of the leading spawn maker's represent a total capital investment of from $\$ 20,000$ to $\$ 50,000$. Because of this only a few growers in the United States have specialized in making spawn. These few, however, make a high 
grade of pure-culture spawn originating from germinated spores and, because of large-scale production and competition, are able to sell spawn cheaper than the average grower could produce it at home.

A list of established spawn makers will be furnished on request by the Division of Mycology and Disease Survey, Bureau of Plant Industry, United States Department of Agriculture, Washington, D. C.

\section{VARIETIES}

Several distinct varieties of the common mushroom are cultivated, but for convenience the trade has grouped them according to the color of the cap, as white, brown, and cream. The terms white

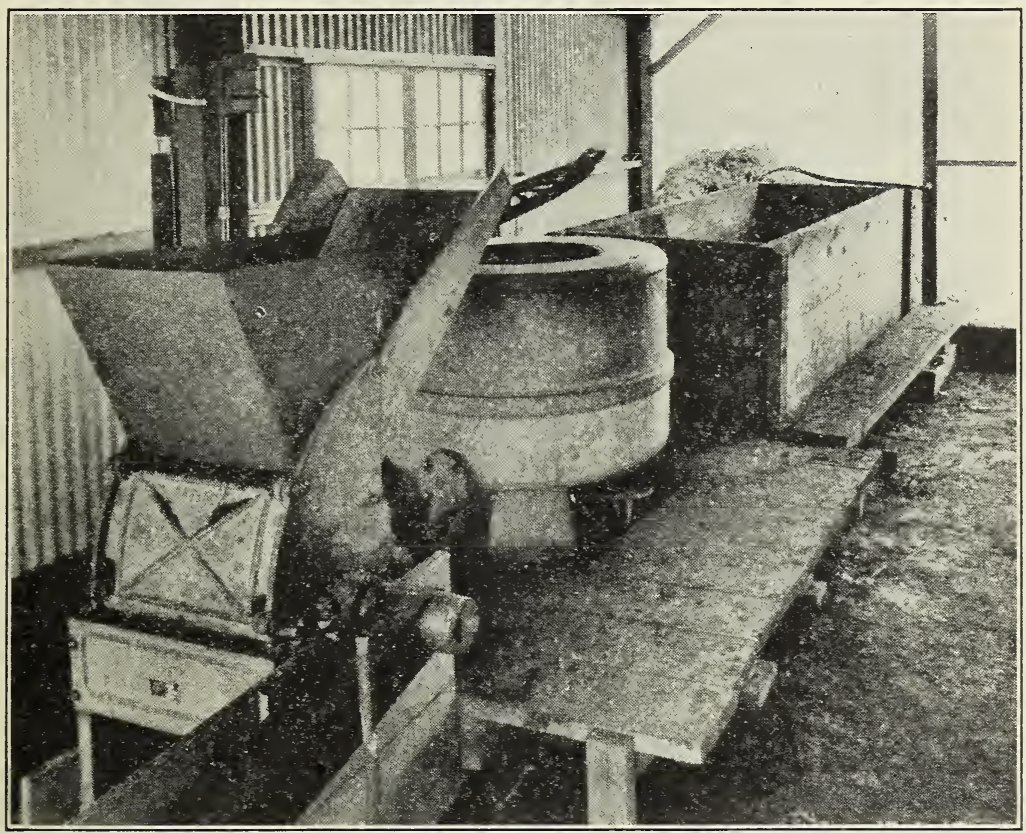

FigLre 6.-Apparatus used to prepare compost for filling spawn bottles

and brown refer to distinct varieties, but there are several cream varieties. The white variety usually commands the highest price on the market, owing to its color. It is prolific but is far from ideal because of its tendency to stain when bruised by handling and to produce clusters on the beds and an excess of button mushrooms. The brown variety is discriminated against in most markets but has advantages over the white in better shipping quality, firmer flesh, and production of fewer button mushrooms. Cream mushrooms are intermediate in color and combine the other characteristics of the white and the brown in different degrees, depending on the variety.

It has been customary to consider all cultivated mushrooms as varieties of Agaricus campestris. However, there are undoubtedly 
heritable differences in the color, form, and growth habits of these so-called varieties which breed true from spores, and in all probability some of them will be considered distinct species when given critical taxonomic consideration.

\section{STRUCTURES FOR RAISING MUSHROOMS}

Mushrooms can be grown in any structure in which the grower can control ventilation, maintain a moderately high humidity, and a range of temperatures between $55^{\circ}$ and $65^{\circ} \mathrm{F}$. Contrary to popular belief, sunlight is not harmful to mushrooms, and they are usually grown in windowless sheds and in caves simply because it is easier and cheaper to control temperature and humidity in structures without windows. Old barns are frequently used. Occasionally waste space in greenhouses is planted to mushrooms. A successful grower

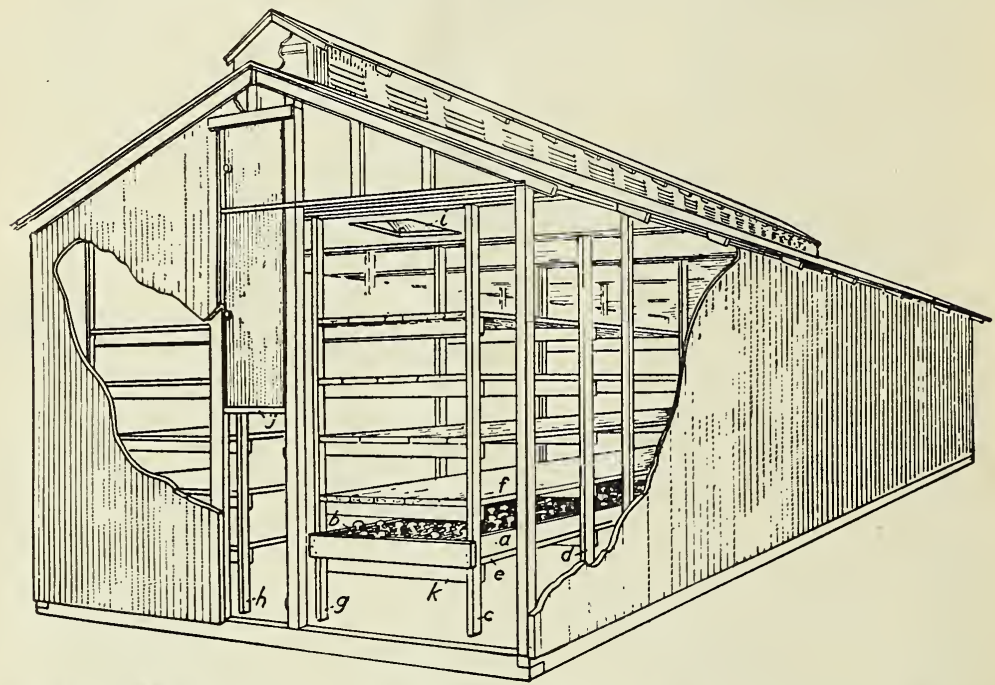

FigURE 7.-Mushroom-house construction. (Letters are referred to in the text)

near Chicago has been growing mushrooms in an old brewery for more than a decade. Sandstone caves along the Mississippi River near St. Paul, Minn., have been used by commercial mushroom growers for more than 40 years. Along the Hudson River near Albany, N. Y., mushrooms are grown extensively in the old ice houses. Near Pittsburgh, Pa., they are grown in partly abandoned mines, and near Akron, N. Y., abandoned limestone quarries have been used for 30 years.

In the industry as a whole, however, the specially constructed house has found most favor, and at least three-fourths of the mushroom crop in the United States is grown in these houses. (Fig. 7.) The principal advantages of the special mushroom house are: It can be suitably located with relation to railroad facilities, markets, and manure supply; ventilation, temperature, and humidity can be easily controlled, the air temperature in the house being raised during final fermentation and the moisture and temperature controlled during the spawn run and the bearing period; separate houses may 
be handled as units during fumigation, and prevent the migration of harmful fungi and insects from old beds to new. The disadvantages are the high initial cost of the house and the high cost of cooling it for the summer crop.

The principal advantages in using caves or mines for growing mushrooms are: The small initial investment, the low temperatures for growing mushrooms in the summer, and the uniform temperature during the growing period. The disadvantages are: The difficulty of disinfecting and ventilating, often a limiting factor in production in these structures; the fact that the temperature around the beds is not raised during the final fermentation; dripping and excessive humidity in summer; the fact that bed temperatures can not be controlled during the spawn run and that distances from railroad facilities, markets, and manure supply are frequently great.

\section{HOUSE CONSTRUCTION}

Commercial mushroom houses are designed to simplify and facilitate such operations as filling the beds, spawning, picking, emptying the beds, disinfecting, fermentation in the house, heating soil, heating, and ventilating. Experience has shown that a house constructed along the general lines shown in Figure 8 meets these requirements.

\section{CONSTRUCTION OF THE BEDS}

In a standard house there are two tiers of beds, 5 to 10 beds high. A space of 6 inches to 1 foot is left beneath the bottom bed to insure a good "heat" (p. 14) during the fermentation of the compost in the bed. A space of 2 feet is allowed between the bottom boards of the beds. (Fig. 7.) These bottom boards are laid in loose in order to facilitate filling and emptying the beds. The side boards ( $a$ and $b$ ) are also loose and are held in place by the compost in the bed. The side boards have been omitted from the upper beds in the figure to simplify the drawing. The beds are usually 6 to 8 inches deep and 6 feet wide ( $a$ to $b$ )-sometimes 5 feet-and run the full length of the house, with the exception of the alleys at the ends of the house. The tiers of beds are supported by 2 by 4 inch uprights ( $c$ and $g$ ) set at 4 -foot intervals $(c$ to $d$ ). The uprights are joined beneath the bottom boards by $1 \frac{1}{2}$ by 6 inch bed supports $(k)$.

\section{ALLEYWAYS}

A space about 30 inches wide is usually provided between the tiers of beds to form a service alleyway which runs the full length of the house. This alley is used in filling and emptying the beds. An elevated runway (level of $j$ ) is built in this alley to make it easier to fill the upper beds. Often the house is built lengthwise into a sidehill with the high ground at the level of the elevated runway $(j)$. An 18-inch alleyway between the outside walls and the tiers of beds is also provided to facilitate picking.

\section{OUTSIDE DIMENSIONS}

The length of the house is usually determined as the result of a compromise between the ideas of a long house economical to build and a short house convenient and economical to fill. Many successful growers consider 65 feet a suitable length. If the house is constructed as shown in the figure, with two tiers of beds ( is about 20 feet. Obviously the height depends on the number of beds in a tier; usually 3 feet is allowed for working space between the top beds and the ceiling. Often several houses are joined together and built alongside each other. When this is done it is customary to make one roof cover four tiers of beds. Two houses joined under one roof in this way are called a double house. 


\section{DOORS}

There are six doors in a mushroom house-three at each end, as illustrated in Figure 7.

\section{VENTILATION}

Mushroom houses must have ventilation systems which provide gradual changes of air with the least possible direct draft over the beds. Ventilation usually is accomplished by occasionally partly opening the doors and opening the hinged rents $(i)$ in the ceiling. To facilitate air circulation the ceiling is sloped upward from the side walls to the ventilators over the center aisle and likewise from one end of the house to the other. In some houses provision is made for drawing the air off the floor and discharging it outside, and the ventilators may be screened to prevent the entrance of mushroom flies.

\section{REFRIGERATION}

Several growers have installed small refrigeration plants to assist them over warm spells in the late spring and early fall and a few have cooling plants extensive enough to enable them to grow mushrooms in the summer. The small refrigeration plants are usually based on the washed-air principle and water pumped from deep wells is used as the cooling agent. The larger plants use mechanical refrigeration, in some cases supplemented with water sprays. In either case the house must be well insulated and the plant must be so designed that it can be cooled without excessive humidity or circulation of air.

\section{HEATING PLANTS}

Mushroom growers usually use hot-water heat. The radiation generally consists of four or five pipes running around the house, hung on the inside of the walls, within a few feet of the floor. In riew of the recently adopted practice of supplying auxiliary heat at the time of the final fermentation, provision (p. 15) should be made for the occasional use of steam.

\section{MATERIALS}

The walls are made of any material having fair insulating value, which will withstand dampness. Many growers make their walls with a single layer of siding, as shown in the figure. Others use a double wall filled with cork. Some use cinder blocks, tile, etc. When the house is built with a ceiling, as in the figure, it is the general practice to cover the floor of the loft with about 5 inches of loose shavings, for heat insulation. The bottom boards and sideboards of the beds are usually made of cypress, which resists rotting.

\section{CAPACITY}

The average mushroom house, 65 by 20 feet, with beds arranged in two tiers six beds high, contains 4,320 square feet of bed space. Since it takes 1 ton of manure to fill 70 square feet of beds, such a house requires approximately 60 tons of manure. It is essential that the manure capacity or bed space be large as compared to the air space, for three reasons; namely, a large proportion of manure to air space insures a better heat during the fermentation in the house; a large capacity makes it easier to maintain a high relative humidity; and it cuts down the capital investment per square foot of bed space.

\section{CULTURAL PRACTICE}

Although there is necessarily considerable difference in the details of the procedure followed by growers under different circumstances, the primary objectives are virtually the same for all. They are the preparation of a suitable compost, the establishment of favorable conditions for growth and reproduction, and the control of fungus and insect pests by routine sanitation and disinfection. 
SELECTING AND STORING MANURE

Commercial mushroom growers use horse manure with straw bedding almost exclusively as the raw material for mushroom compost. Practical experience has led them to prefer manure from grain-fed horses bedded with a moderate amount of wheat straw. Manure with too much straw has a tendency to dry out and cool off because of excessive evaporation. Good mushroom crops have been obtained from manure with rye straw, oat straw, or even pine shavings as bedding, but these materials require special treatment. Rye straw is usually longer and more difficult to break up than wheat straw; oat straw breaks down very rapidly and has a tendency to overheat and become moldy; shavings manure makes a compact heap and requires more thorough aeration than straw manure. Certain growers have successfully handled strawy or "long" manure from racing stables by heaping it twice as high as ordinary manure at the beginning of the composting period. In large cities, such as New York, Philadelphia, and Chicago, the manure is handled by brokers who contract with the stable owners and resell by the carload to truck gardeners and mushroom growers.

The manure is usually composted as soon as a rick is assembled sufficient to fill the mushroom house, but at times it must be stored. When storage is necessary the method most generally practiced is to pile the manure into large compact heaps from 8 to 10 feet high and containing at least 90 tons. The heaps are then covered with several inches of soil and allowed to stand undisturbed except for an occasional watering of the outside layer. Manure handled in this way can be successfully stored for three or four months. Apparently the manure remains in better condition if moist, anaerobic conditions are maintained inside the rick to check fermentation and keep the compost "green."

COMPOSTING THE MANURE IN THE RICK

Composting the manure is probably the most variable operation in mushroom culture. Manure assembled for different ricks, or even for different parts of the same rick, is seldom exactly alike. Successful growers attempt to allow for these differences by accommodating their composting procedure to the kind of manure. They keep in mind what they consider ideal composting conditions and ideal texture and appearance of the finished compost rather than a set procedure for handling the manure.

The most important factors affecting the compost that may be controlled by the grower are aeration, moisture content, and temperature. These are largely dependent on the size and shape of the rick, its height, compactness, the amount of water added during turning, and the number of days between turnings. The lateral dimensions of the heap are usually determined by the space available for composting and the amount of bed space to be filled. Ricks for commercial mushroom culture usually contain 60 to 100 tons of manure, and are about 20 feet wide by 40 to 60 feet long. The height of the rick depends somewhat on the texture of the manure. 'The a verage 
manure with a moderate proportion of straw to droppings is piled up from 4 to 6 feet high when first assembled. Manure containing an excess of straw has a loose texture and will shrink to one-fourth of its bulk during composting. Therefore manure of this type is piled up 6 to 8 feet high when first assembled and should be weighted down with a layer of soil or boards during the early stages of fermentation. Some growers always spread a layer of soil over the top of the rick to make it more compact and to help conserve the moisture; others consider the soil unnecessary and regulate the moisture entirely by watering during the composting. In either case the height of the rick is allowed to recede as the manure shrinks during composting until it is about 3 or 4 feet high at filling time.

The ricks are usually allowed to stand undisturbed for 10 days after they are assembled before the first turning. The turning is usually done by hand although a few growers use special machines. During the first turning water is applied to the dry straw, the caked manure is broken up, and the sides of the heap are turned in to the center. This process is repeated at intervals of from a week to 10 days until the compost is in proper condition to go into the house. The object of the turning is to aerate the manure, break it up, thoroughly mix it, and maintain a moderate moisture content throughout the rick. Success or failure depends very largely on the moisture content of the rick during fermentation.

Excessive watering causes a "greasy" compost, sometimes called "black butter," which favors the development of a disease called "plaster mold" on the bed and may be difficult to dry out sufficiently to enable mushroom mycelium to run. On the other hand, too little water slows down the fermentation and may cause an excessive drying out and burning. The average grower maintains about 150 to 250 per cent water (on a dry-weight basis) in his heap, although this differs with different seasons, different types of manure, and different stages in the composting period. In general, the manure may be said to be moist but not wet, and a larger water content is allowable at the beginning of the composting period than at the end. As a rule, heavy watering is confined to the first turnings. The objective toward the end of the composting period is to obtain a condition slightly more moist than the optimum for the growth of mycelium, in order to allow for a small loss of water during the final fermentation in the house.

The grower's practical test for this moisture content is to squeeze a ball of compost tightly in the hand. If the hand is not moistened the compost is too dry; if water oozes out freely between the fingers the compost is too wet. Manure in a desirable condition contains about 150 to 175 per cent water as compared to dry matter. Experienced growers know the great necessity of avoiding a soggy condition toward the end of the composting period. Such a condition is one of the most common causes of failure. Mushroom mycelium will not run in wet manure and the compost will not heat properly in the bed. During cloudy weather ricks often become more moist toward the end of the composting period without any water being added. Growers refer to this change as "taking up water." Probably the apparent taking up of water is really a more rapid loss of dry matter 
in the form of carbon dioxide, coincident with a lowering of the water-holding capacity of the compost.

The most desirable interval between turnings and the duration of the composting period depend on the nature of the compost. Weekly turnings are generally considered most satisfactory, but if the manure is short a uniform compost may be obtained with intervals of 10 days between turnings. In the Pennsylvania region. where manure is shipped in by the carload, it usually has been handled several times before the grower receives it. Under these conditions a composting period of 25 to 35 days is generally sufficient. This would include 10 days from the time of assembling to the first turning and two or three turnings at weekly intervals. When long manure is obtained fresh from the stables, six weeks may be necessary with four or five turnings. In any case the real criterion of the end of the composting period is the condition of the compost. Well-composted manure is fairly uniform in color and texture-a dark chocolate brown moderately speckled with white; the straw is pliable enough to shear off readily when torn crossways; when squeezed the compost just moistens the hand without water running out and at the same time is sufficiently moist and decomposed to remain in a ball when so molded. When this condition is reached the compost is ready for making beds and is taken into the house about three days after the last turning.

The Department of Agriculture is often requested to determine whether samples of manure are suitable for mushroom culture, and whether they are sufficiently composted to be ready for making beds. Aside from detecting specific harmful material in the manure, no laboratory procedure known can satisfactorily answer either question. Often composts which are radically different in nutritional value for the growth of mushrooms will have approximately the same appearance and chemical analysis. When sufficient experimental data have been accumulated, an approximate organic analysis, or even a simple determination of the carbon-nitrogen ratio, or the reaction (hydrogen-ion concentration) of the manure, may aid in determining the proper degree of decomposition of the compost. At present, however, not enough is known about the extent to which these attributes are correlated with potential mushroom yield to warrant substituting them for judgment based on the appearance and feel of suitable compost.

Inquiries for exact information on the optimum conditions for fermentation of the compost and for methods of inducing the most favorable bacterial flora are also received occasionally. Circumstantial evidence suggests that the type of microbial flora which predominates during the composting period may have a profound influence on the subsequent yield of mushrooms. Also, that in all probability the predominating flora of the compost heap at a given time is largely dependent on the variable factors of aeration, reaction, moisture content, and temperature. Theoretically it should be possible to determine and establish the optimum combination of these factors. But no precise information is at present available. and solution of the problem must await a considerable amount of careful experimentation under controlled conditions. 
FINAL COMPOSTING IN THE BED

A few of the larger growers run the manure into the house from the ricks on a series of belt conveyors driven by electric motors (fig. 8), but most of them use bushel baskets set in a row on long, narrow cars which run on light, narrow-gauge tracks. The manure is placed in the beds at the rate of 1 bushel to approximately 2 square feet of bed space. If the compost is wet, or has approximately the correct moisture content, it is allowed to lie in the beds loose or only slightly packed during the heating process. If it is too dry it is packed to help retain the moisture.

A standard house is usually filled in one or two days; the house is then sealed up tightly and the manure is allowed to go through a final fermentation for a few days. High temperatures are generated inside the house by the manure and the whole procedure is referred to as putting the manure through the "heat." This heat serves three purposes: (1) It allows the grower to dry out the

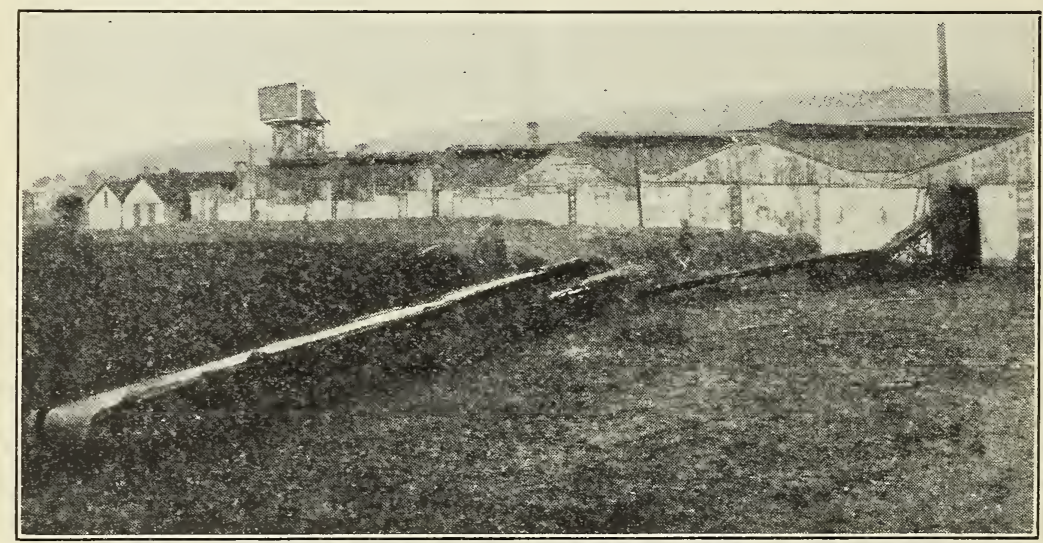

Figure 8.-Filling a mushroom house by the use of belt conveyors

manure if it is too wet; (2) it eradicates many harmful insects and fungi which have been taken into the house with the manure; and (3) it seems to bring about a healthier and more rapid run of spawn, presumably because of a more favorable biological balance or nutritional condition in the compost.

The temperature usually begins to rise a few hours after the house is closed and under favorable conditions continues to rise slowly until the air temperature throughout the house reaches $120^{\circ}$ to $130^{\circ} \mathrm{F}$. and the temperature of the manure in the beds is $130^{\circ}$ to $145^{\circ}$. These temperatures are maintained for 12 hours or, if the compost is too wet, until the excess water is driven out. At the peak heat calcium cyanide is usually dusted in the aisles or a small amount of sulphur is burned in the house to kill any insects which may be driven to the surface of the beds by the heat (p. 28). The temperature is then lowered slowly to $75^{\circ}$ for spawning.

The principal difficulties encountered during the heat are: $\mathrm{A}$ tendency for the temperature in the upper part of the house to run $10^{\circ}$ to $20^{\circ} \mathrm{F}$. higher than that in the lower part; an excessive con- 
densation of moisture on the upper beds; and a lack of sufficient heat in the manure or insulation in the house walls to maintain the desired temperatures. It is usually difficult to make floor beds heat properly, and therefore it is advisable to raise them a few inches or abandon them entirely. The tendency toward temperature layering may be largely offset by rumning electric fans set vertically or at an angle of $45^{\circ}$ in the aisle during the heat. In most cases the condensation of moisture on the surface of the top beds can scarcely be avoided, but its harmful effect can be reduced by filling the top beds with the driest manure and casing these beds with dry soil. Houses that fail to heat up properly can usually be brought up to a desirable temperature without excessive wetting or drying out by a combination of live steam and hot water or steam radiation. This practice has given satisfactory results in the Department of Agriculture's experimental house during the seasons of 1928 to 1931, inclusive.

While the temperatures mentioned above are considered best by many practical growers, the question of what is the most favorable temperature is by no means settled. Theoretically the minimum air temperature should be based on the thermal death points of insect and fungus pests, and the maximum manure temperature should be established by studies, under controlled conditions, of the effect of the temperature during the final heat on the flora of the bed and on the yield of mushrooms. The final answer to this question will undoubtedly be a compromise between these two considerations. In the meantime it would seem to be sound practice to follow the lead of practical experience and avoid air temperatures lower than $120^{\circ}$ and bed temperatures above $145^{\circ} \mathrm{F}$.

When mushrooms are grown in abandoned buildings the foregoing conditions can often be obtained, but in old mines or cares the air temperature can not be raised and the final heat can only be approximated in the beds. The beds are usually made on the floor (fig. 9) and more manure is used to prevent the temperature from dropping too low during the period when the spawn is beginning to run. With a deeper bed, 12 to 14 inches, the manure may have a tendency to overheat and firefang a few days after the beds are made. To prevent this the beds are sometimes packed by being trampled with the feet over the entire surface.

\section{MANURE SUBSTITUTES AND SUPPLEMENTS}

Several years ago investigators at the Rothamsted Experiment Station in England discovered that artificial manure comparing favorably in appearance and chemical composition with stable manure could be made by composting straw or other material high in cellulose with nitrogenous fertilizers. The essential features of their process, which has been patented in the United States under patents Nos. 1471979 and 1619679, are the addition of fertilizer to plant refuse so as to add about three-quarters of a pound of nitrogen to every 100 pounds of dry plant refuse, wetting the material and adjusting the reaction to a slight alkalinity. As a result of these investigations there arose a question whether compost suitable for mushroom culture could be made by this process from straw, peat, or other plant refuse. 
A few commercial growers have experimented along this line for several years, and the problem was undertaken by the United States Department of Agriculture and the Pennsylvania Agricultural Experiment Station in 1928. The experiments made in the department have shown that the English process must be modified in order to obtain a fermentation similar to that in mushroom compost. The physical condition of the heap must be made similar to that of composted stable manure, the heap must be wetted and aerated in the same manner as mushroom compost, and the nitrogenous fertilizers must be supplemented with other nutrients. The cost of artificial compost made with straw depends largely upon the cost of straw, but since enough artificial compost can be made from a ton of dry straw to fill as much bed space as 3 to 5 tons of stable-manure

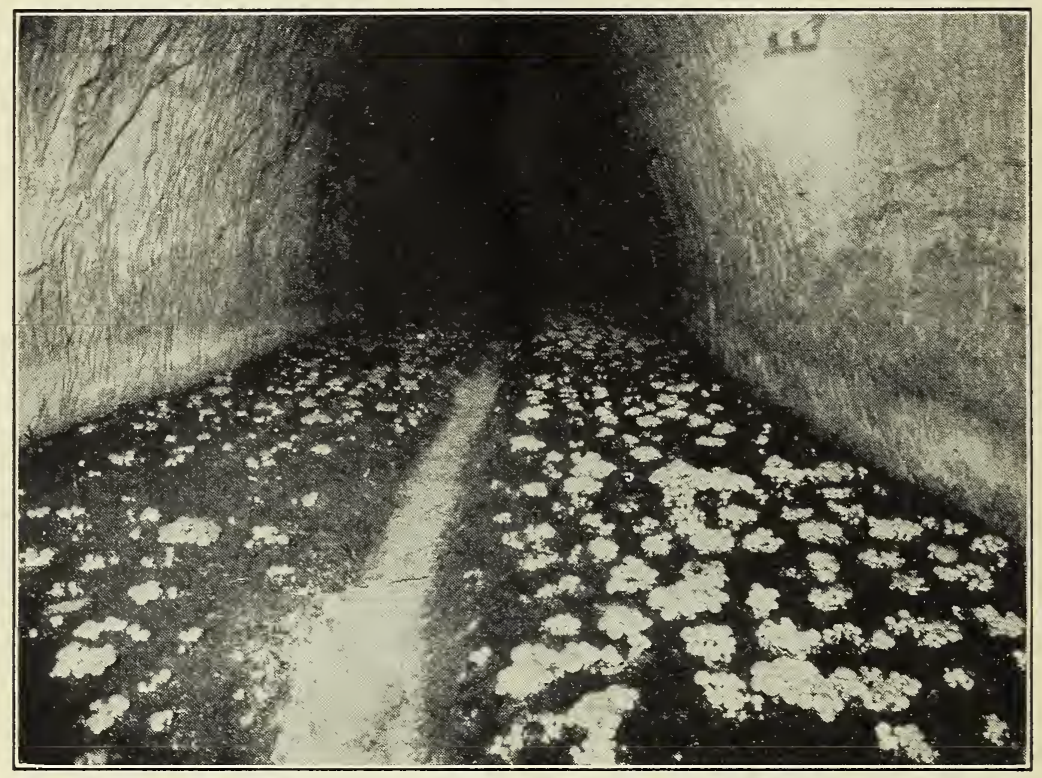

Figure 9.-Floor beds in a cave, St. Paul, Minn.

compost will fill, the cost of the finished artificial compost, in most localities, should be about the same as that of stable-manure compost, or less. A straw compost, properly handled, will yield a crop of more than 1 pound of mushrooms per square foot when used alone or mixed with stable-manure compost. (Fig. 10.) However, the average yields from artificial manure in the experiments of the department at the Arlington Experiment Farm in Virginia have been lower and more inconsistent than yields from composted horse manure. The reasons for these inconsistencies are not thoroughly understood. Therefore, although the experiments appear promising, the department does not advise the use of artificial manure for commercial mushroom growing until more experiments have been made. In experimenting with artificial manure on a small scale the following recommendations should be observed: 
It is advisable to make the straw-compost heap at least twice as high as ordinary mushroom-compost heaps because of much greater shrinkage in the straw heap during composting.

The air spaces between the straw in a freshly made pile must be reduced to a size similar to that of the air spaces in horse manure in order to avoid excessive loss of water and heat. This can be done by adding soil or other material to take the place of the droppings, by weighting down the heap, or by chopping up the straw.

Several nitrogenous fertilizers are suitable; some of the most promising are dried blood, calurea, and cyanamid.

The minimum amount of nitrogen fertilizer necessary to obtain a satisfactory compost has not been determined, but any of the foregoing materials will make a fair compost if supplied at the rate of about 10 to 20 pounds of nitrogen per ton of dry straw.

When the useful mineral elements in straw are compared with those found in stable manure there appears to be a shortage of phosphorus and calcium, but care must be taken in adding these materials not to upset the reaction of compost.

If an acid material such as ammonium sulphate is added to the heap it should be neutralized. This is usually done by adding lime.

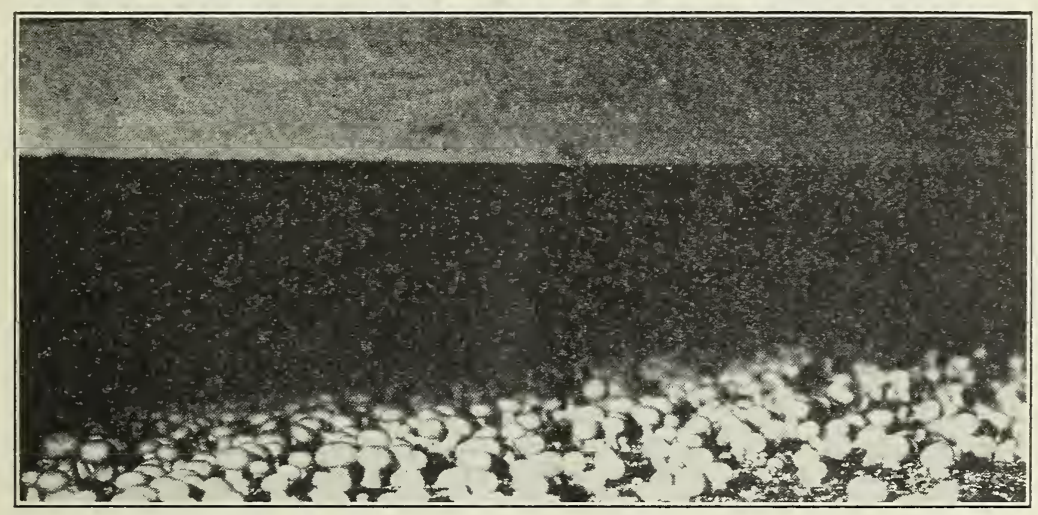

Figure 10.-Mushrooms on an experimental bed of artificial manure (made by composting $i$ ton of straw with 100 pounds of dried blood and 50 pounds of calurea)

The fertilizers should be well scattered throughout the heap and the compost wet down and handled in the same way as mushroom compost. To prevent leaching, it is a good plan to wet the straw before adding the fertilizer.

Results obtained from preliminary experiments suggest that artificial compost is suitable to be made up into beds when slightly less decomposed and drier than properly composterl horse manure. For the present the experimenter may expect more work and fewer mushrooms with artificial compost than with ordinary stable-manure compost.

The question whether horse manure can be improved for mushroom culture by adding such materials as ground limestone, commercial fertilizers, or peat muck, often arises. Theoretically these materials might be of value in increasing the alkaline reserve of the manure, supplying minerals or organic material of nutritional value to the mushroom, or improving the physical condition of the heap. In France favorable results from adding Thomas slag to manure are reported; while in the United States benefits from adding cottonseed meal have been reported, a few growers add ammonium sulphate to the manure, some add limestone or gypsum, and others peat muck. But so far as the writer can ascertain these practices are based on 
meager evidence, and for every grower who is of the opinion that manure is benefited by the addition of a certain material there are others who claim to have tried the material without success. This difference in opinion easily might be due to differences in the source of manure used by the different growers or to variation in the yield obtained in different houses because of different combinations of circumstances. Therefore, it would seem to be sound practice for the commercial grower to confine his activities along this line to small experiments until he has convinced himself of the value of the practice or until State experiment stations or the Department of Agriculture have published convincing experimental evidence.

\section{SPAWNING AND CASING}

The spawn is inserted in the beds as soon as the temperature in the compost has receded to $75^{\circ} \mathrm{F}$. Most spawn makers advocate using spawn pieces about one-half as large as a hen's egg and spacing them about 8 inches to 1 foot apart in the bed. An imperial quart bottle of spawn supplies about 35 to 40 such spawn pieces. The spawn is removed from the bottle by breaking the bottle and the pieces are inserted in the bed about $11 / 2$ inches from the surface. After the spawn is inserted the temperature of the bed is usually maintained between $70^{\circ}$ and $75^{\circ}$ for a week or 10 days to insure a good "catch" of spawn. It is then dropped slowly until the desired cropping temperature is reached. The mycelium undoubtedly grows most vigorously at about $75^{\circ}$ in both sterilized and unsterilized compost (fig. 11), but in most cases it is not desirable to maintain a temperature as high as this for more than 10 days because of the increased insect activity at the higher temperature and the tendency for the beds to dry out excessively.

The casing of the beds consists simply of spreading soil about 1 inch thick over the beds from two weeks to a month after spawning. It is evident from the widespread distribution of the industry that suitable casing soil may be found in most sections of the United States. One of the primary characteristics of soil for casing is its water-holding capacity. A good casing soil will tenaciously retain water and dry out uniformly without cracking or forming a crust on the surface. Successful growers believe that neutral clay loam soils with a fair amount of organic matter make the best casing soil. Subsoil and acid sandy soils are avoided and the practice of neutralizing soil with lime has gained favor in recent years. More specific recommendations than these must await systematic experiments under controlled conditions.

Many growers purchase and maintain small fields especially for casing soil. After stripping the upper 6 inches of a part of the field for casing soil they pass on to other parts in succeeding years. Meanwhile the subsoil of the stripped portion is built up by liming if necessary and by growing a green cover crop to add humus to the soil. A rotation of this kind is usually planned so that an interval of four or five years elapses before soil is taken a second time from any part of the field. It is important to make sure a field for casing, soil is not contaminated with the fungus causing the "Mycogone" or "bubbles" disease of mushrooms. The accepted practice is to avoid all fields that have been previously fertilized with spent mush- 
loom manure or that may be contaminated by cattle, horses, drain water, etc., from such fields. These precautions are especially necessary in congested centers of mushroom growing. If there is any doubt about the presence of the fungus in the soil it should be used on small test beds before risking its use on a large scale. When no Mycogone-free soil is available the fungus may be eradicated from the soil by heat treatment as described later in the discussion of

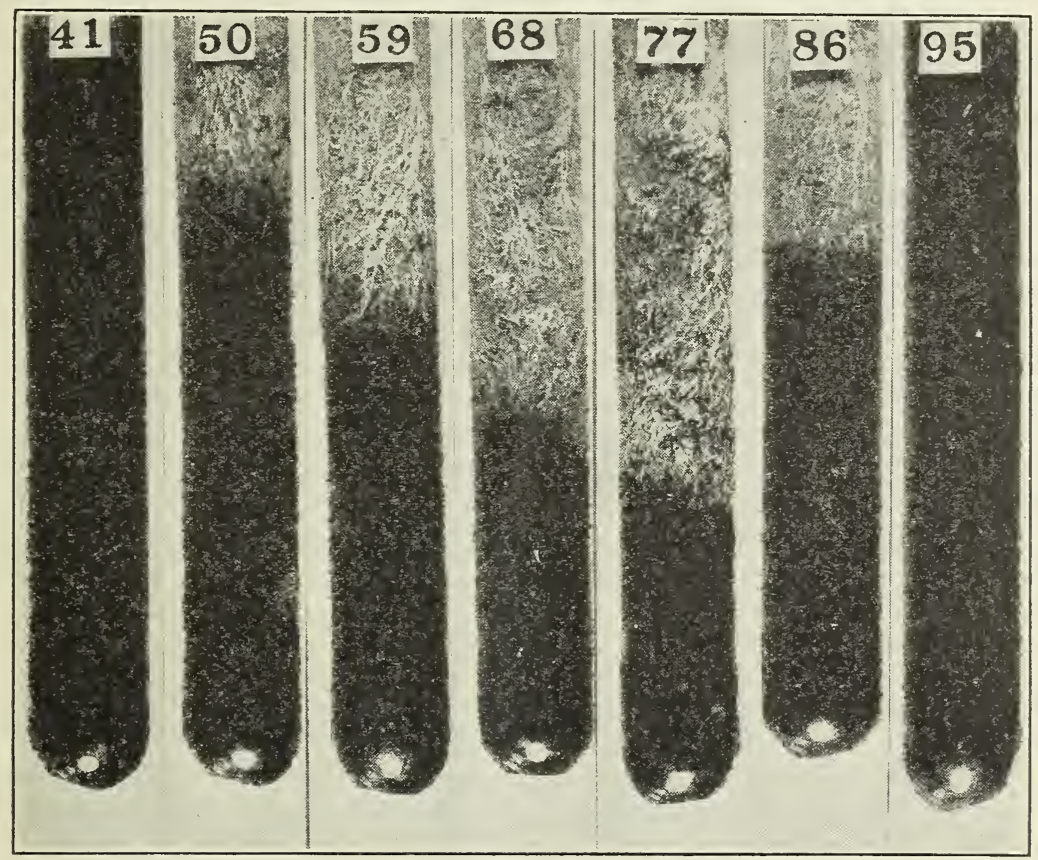

Figure 11. - The effect of temperature on the rate of growth of mushroom mycelium in compost. The numbers at the top of the test tubes refer to the incubation temperatures in degrees Fahrenheit

mushroom diseases. In a disease-infested area care must be taken from the digging of the soil to the screening and placing on the beds to prevent the soil from coming into contact with contaminated tools.

\section{GROWING CONDITIONS}

\section{TEMPERATLRE}

The temperature at which the house is held largely determines the length of the growing period and has considerable influence on the quality of the mushrooms. If the temperature is kept between $45^{\circ}$ and $55^{\circ} \mathrm{F}$. good beds continue to bear mushrooms for five or six months, whereas in a house held at $60^{\circ}$ to $65^{\circ}$ the beds exhaust themselves in three months. In the former case, as a rule, the mushrooms grow somewhat larger and are distinctly firmer and heavier than those grown at the higher temperatures. The total yield is approximately the same with perhaps a slight advantage in favor of the beds held within the low temperature range. When two or more crops are grown in one season, time is an important 
consideration and the beds must be kept above $55^{\circ}$. The practice of maintaining a uniform growing temperature is widely favored, although many growers prefer to start their crops at a low temperature and bring on successive growths of mushrooms at slightly higher temperatures. The temperature limits at which the common cultivated varieties of mushrooms can be grown are $45^{\circ}$ to $68^{\circ}$. Lower temperatures delay the crop but do not permanently injure the beds. On the other hand, during the time when the mushrooms are on the beds a period of more than a few lays with a temperature in the house over $70^{\circ}$ will often injure the crop seriously.

\section{HUMIDITY}

The relative humidity in the average mushroom house during the bearing period ranges from 70 to 80 per cent. This condition is easier to maintain in some houses than in others because of the difference in the exchange of air through cracks and crevices and differences in the proportion of air space to bed space. When the humidity is allowed to drop much below 70 per cent the casing soil has a tendency to dry out too quickly and the surface of the mushrooms becomes tough and under extreme conditions cracked and seamed. Conversely, if too high a relative humidity is maintained. the mushroom disease known as "spot" will be aggravated by the reduced rate of evaporation of the contaminated water spattered on the mushrooms during the watering of the beds.

\section{WATERING}

Procedure in watering mushroom beds is governed largely by two objectives: Maintaining in the soil the proper moisture content to induce therein an abundant growth of healthy mushroom strands or rhizomorphs; and minimizing the number of spots and blemishes on the surface of the mushrooms caused by water spattered on growing mushroom caps. Usually, water is first applied to the beds shortly after they are cased. At this time the beds are watered lightly every day until there is just sufficient moisture in the soil to cause normal strand formation throughout the soil laver. This moderate moisture content is maintained until the mushrooms begin to appear. Care should be taken to avoid an excess of water in the soil at this time, as it may prevent normal strand formation and seriously reduce the subsequent yield of mushrooms. The amount of water necessary to maintain the proper moisture content is quite different for different soils and in different localities and seasons. It depends on the relative humidity in the house, the moisture content of the compost, and the water-holding capacity of the soil. In general, several light waterings are preferable to a few heavy ones because of the danger of excess water percolating through the soil and causing the formation of a wet layer of manure under the soil. Such a layer may prevent the healthy mushroom mycelium lower in the bed from growing up to the soil. Puddles of water on the bed are also objectionable because they tend to stimulate the development in the soil of a harmful green mold and to cause submerged pinhead mushrooms to turn brown and die. On the other hand, if the soil is too dry or if only the upper layer is moist, fewer mushrooms will 
develop, and the first mushrooms to come up will have a tendency to form beneath the soil layer rather than on the upper surface.

After the mushrooms begin to appear they usually develop in sudden outbreaks at intervals of about a week. These outbreaks are called "flushes" or "breaks" and are followed by periods during which there are only a few mushrooms on the beds. (Fig. 12.) There are sereral systems of watering in relation to these breaks. Some growers water only between breaks so as to avoid wetting the mushrooms. Others water lightly two or three times a week regardless of the breaks. Many follow a compromise system of watering regardless of the breaks during the first three breaks. During thise period spotting is not serious because the fresh mycelium is vigorous and harmful fungi and bacteria in the soil are comparatively scarce. Thereafter, watering is done only between breaks. In any case, when water is applied to the beds while mushrooms are growing a gentle

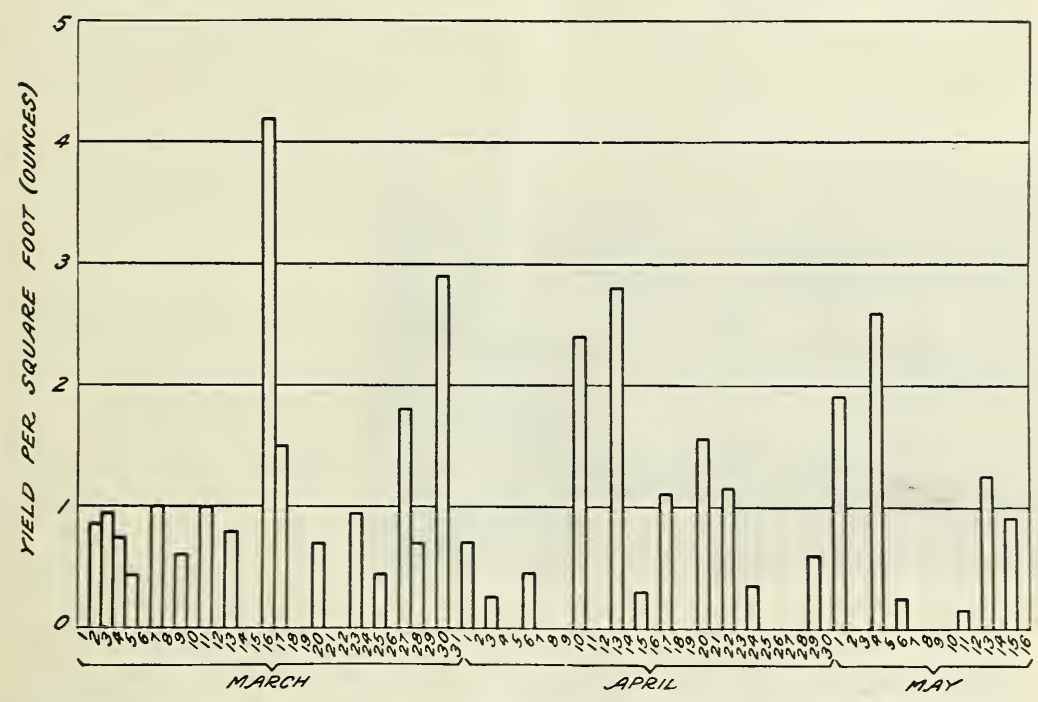

FIGURE 12.-Graph showing the daily yield of mushrooms from a test bed (10 square feet) at Arlington Experiment Farm, Rosslyn, Va. Note cycles of growth referred to by growers as "flushes" or "breaks",

shower is used to avoid spattering soil on to the caps of the mushrooms, and ventilation is increased after watering until the droplets on the mushroom caps are evaporated.

VENTILATION

Considerable ventilation is necessary in growing a good crop of mushrooms, and it is advisable to give as much ventilation as possible without interfering with temperature and humidity control or causing excessive evaporation from the beds by cross drafts. Usually it is easier to ventilate, without interfering with these factors, in the spring and fall months. When the temperature outside the mushroom house is higher than that inside, the fresh air will become damp upon entering the house. Conversely, cold air brought into a warm mushroom house absorbs moisture and will have a tendency to lower the relative humidity inside the house. 


\section{SANITATION AND DISINFECTION}

As congested centers of mushroom growing develop (fig. 13) it is becoming more and more apparent that cumulative losses caused by fungi and insect pests can scarcely be avoided unless a carefully planned program of disinfection and sanitation is made a part of the routine of cultural practice. It is advisable to thoroughly disinfect the composting grounds and the mushroom house between crops and to take special precautions to prevent the contamination of casing soil and water.

A few growers have concrete composting surfaces, but in most cases the manure is composted on the bare ground and a sanitary condition is maintained by keeping the ground free from old manure and standing water between crops and by thoroughly drenching the soil with a disinfectant a few weeks before assembling the manure. A solution of formaldehyde made by dissolving 1 pint of fresh for-

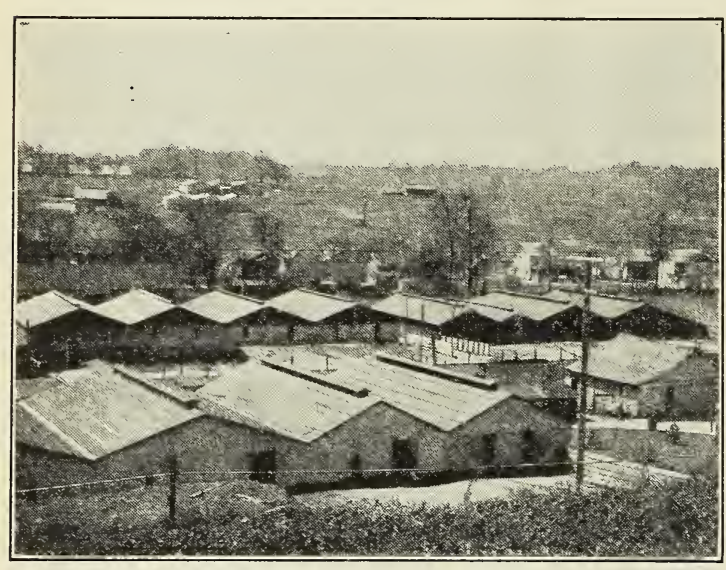

Figure 13.-Mushroom houses near Toughkenamon, Pa. malin in 15 gallons of water has satisfactory germicidal properties for this purpose and in addition has the advantage of being noncorrosive to metals and of remaining only temporarily in the soil.

It is almost a universal practice to thoroughly disinfect the inside of the mushroom house a few weeks before filling time either by burning sulphur or releasing formaldehyde gas. Effective fumigation may be obtained by either method, especially under warm, damp conditions, but both sulphur fumes and formaldehyde gas are injurious to growing mushrooms and special precautions are necessary when fumigating a house adjacent to one in which a crop is growing.

When sulphur is used it is usually burned at the rate of 5 pounds per 1,000 cubic feet of air space. Either crude sulphur or flowers of sulphur will burn readily with the aid of rag wicks soaked in kerosene. Deep containers must be used and air pockets in the sulphur heap must be avoided in order to minimize the fire hazard of running molten sulphur and burning sulphur spattering over the bed boards. It is not advisable to burn sulphur directly on the cement floor of the alley, since the heat generated may cause the cement to buckle and throw out particles of burning sulphur. Some growers burn the sulphur outside the house and use a forced draft to blow the fumes into the house.

Fumigation with formaldehyde is accomplished by vaporizing commercial formalin-40 per cent formaldehyde solution in waterat the rate of 1 quart to 1,000 cubic feet of air space. The formalin 
is usually placed in pails or tubs along the alley and vaporized by adding crystals of potassium permanganate at the rate of 1 pound per quart of formalin. As in fumigating with sulphur, all preparations for quickly leaving and closing the house should be made before the gas is released and exposed lights should not be used in the house, since formaldehyde gas is explosive under certain conditions.

While the crop is being picked all mushrooms affected with bubbles should be carefully removed from the house and burned to prevent the spread of the disease. After doing this work the men should thoroughly disinfect their hands. It is also advisable to burn all mushroom refuse. After each crop all traces of spent manure should be removed and disposed of so that none will be used on fields near the mushroom house or where it can possibly contaminate prospective casing soil.

The water supply also should be carefully guarded against contamination with fungus spores or any traces of grease or oil which might cause diseased or deformed mushrooms.

For general disinfecting around the packing house, or disinfecting workmen's hands or diseased areas on a bed, commercial preparations having carbolic acid, creosote, hypochlorite, or mercury as active ingredients are widely used.

\section{DISEASES}

There are three general classes of mushroom diseases: Those caused by parasitic fungi or bacteria; those caused by fungi which make conditions unfavorable for the mushroom by growing like weeds in the bed; and those that cause malformation of the mushroom apparently stimulated by nonliving irritants. The bubbles and spot are examples of the parasitic class, plaster mold and truffles are examples of the weed type, and rose comb is an example of the irritant type. Certain of the more important of these are described on the following pages.

BUBBLES

Bubbles is the most destructive disease of cultivated mushrooms. It is caused by the fungus Mycogone perniciosa Magn. which grows into the mushroom and transforms it into a distorted, putrid mass. (Fig. 14.) Soon after the mushroom is attacked the parasite produces a layer of white or brown spores orer the surface. These spores may be spread by various agencies and are able to live through a long rest period under unfavorable conditions. The recurrence or accumulation of the disease from one crop to another indicates that the fungus either is remaining alive inside the house from one crop to another or is being carried into the house during one of the cultural operations. There are several possible methods of introducing the fungus into the house-in the air or on insects entering through doors or ventilators, or in the water, spawn, compost, or soil, or on the clothing or hands of workmen.

If the house is thoroughly disinfected with either sulphur or formaldehyde there is practically no chance for inoculum to remain in the house from one crop to another. Likewise, disinfection of the area surrounding the house and sanitary disposal of mushroom refuse will materially reduce the danger from wind-blown or insect-carried 
spores. If an open well is used it may be necessary to disinfect it occasionally. There is little chance for Mycogone to be spread in bottle spawn that has been made under aseptic conditions.

Mycogone is killed by long exposure to moderately high temperatures. All the evidence at hand indicates that a temperature of $120^{\circ}$ F. for 48 hours in a mushroom house will eradicate the fungus from the house, and the manure in a house which has been through a good heat should be free from Mycogone. This and other circumstantial evidence indicates that most severe outbreaks of bubbles in commercial houses are due to carelessness in disinfecting the house or to infested casing soil.

Losses from infested casing soil can be eliminated by taking precautions to prevent the contamination of the soil. To determine

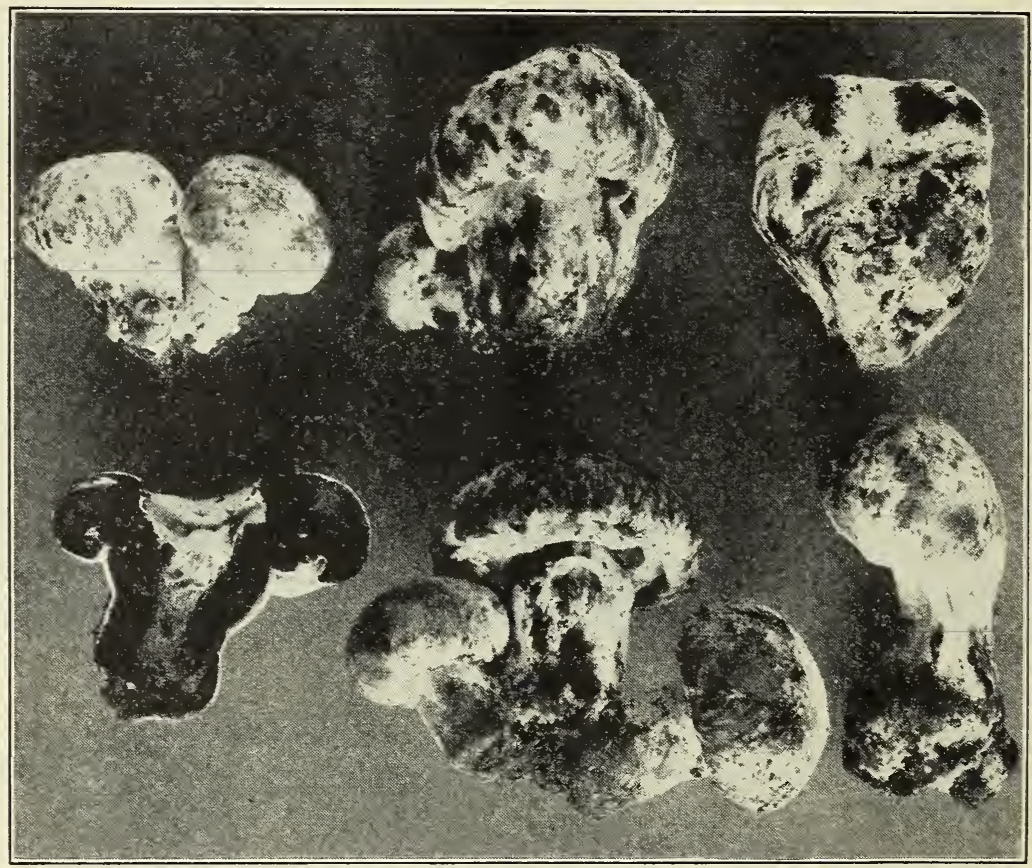

Figure 14.-Mushrooms distorted by the bubbles or Mycogone

whether soil is contaminated, small test beds may be cased with soil samples taken from fields that are to be used as sources of soil for subsequent crops. If soil infestation becomes general and there is no Mycogone-free soil available, the fungus can be eradicated by heating the soil to at least $120^{\circ} \mathrm{F}$. for 48 hours. This can be done in specially equipped rooms, or by placing the soil in trays near the top of the house during the heat, if the heating plant is large enough to raise the temperature artificially in the event that the manure does not generate sufficient heat. When the soil is heated to more than $150^{\circ}$, Mycogone spores are killed in less than an hour. Some growers find partial sterilization with live steam, as described in Farmers' Bulletin 1629, quite satisfactory. Others complain of a loss of water-holding capacity and molding of the steamed soil. The 
injurious effect of steaming apparently raries with different types of soil and in many cases is temporary and can be eliminated by steaming some time prior to casing, or by aeration of the steamed soil.

After the disease has become established in a house strict sanitary measures are necessary to prevent workmen from spreading it. The loss may be reduced somewhat by growing the crop around $50^{\circ}$.

The measures outlined above apply particularly to the prevention of the disease in conventional mushroom houses, but the principles may be applied to most situations.

\section{BACTERIAL SPOT}

The spot disease of mushrooms caused by Bacterium tolaasi (Paine) Elliott and other soil organisms is found wherever mushrooms are grown commercially. It is the most troublesome disease in cares and is often quite serious in standard houses, especially toward the end of a crop period or in growing summer crops in artificially cooled houses. It is characterized by brown, almost black, spots over the surface of the mushroom cap. These spots are often corered with a bacterial ooze. Usually they do not penetrate deeply into the mushroom flesh, but at times the bacteria follow along the tunnels of fly larrae and blacken the entire stem and parts of the cap. Infection is known to be farored by high humidity and prolonged wetting of the mushroom caps while watering the beds. Circumstantial evidence indicates that the inoculum comes principally from the soil. Growers should endearor to aroid spattering water from the soil on to the mushrooms, take erery precaution to prevent the house from becoming too damp, and, weather permitting; attempt to dry off the mushrooms rapidly after watering by opening the doors and rentilators for a fert minutes. Mushrooms on old beds seem to be more subject to spotting than do new breaks and at times poor rentilation seems to be an aggrarating factor.

\section{OTHER DISEASES}

The "green mold" disease spreads in patches from the masses of mushroom tissue which are sometimes left in the soil after picking. Once a patch of the fungus causing this disease becomes established in the soil, more button mushrooms are rarely formed in that area. Its development can be retarded by removing all of the solid fungus tissue at the base of the mushrooms when picking them, and filling the holes with fresh soil. Excessive dampness should also be avoided. Liming seems to be somewhat beneficial as a prerentive but not as a control measure.

The presence on the bed of a large proportion of deformed mushrooms with superfluous gills over the upper surface of the cap resembling the rose comb of poultry and sometimes deeply seamed and cracked has been traced in many cases to mineral oil or oil products. In some cases abnormalities were apparently due to the use of kerosene in smudges, disinfectants, and insect sprays. In others they were due to accidental contamination of the water supply with oil or grease.

Among the diseases caused by competitive fungi in the mushroom bed the white plaster mold (sometimes called "flour mold") and truffles are the most troublesome. The former is caused by a fungus, 
Monilia fimicola Cost. and Matr., which produces a grayish spore dust throughout the interior of the compost. When this fungus is abundant in the beds the mushroom mycelium rarely grows more than a few inches from the spawn piece and a total crop failure often results. In some cases the origin of serious infestation with this mold has been traced to contaminated brick spawn. Usually severe outbreaks are due to insanitary conditions around the mushroom house or to a wet, soggy condition of the manure at filling time.

The truffles disease is characterized by the development of creamcolored wefts of fungus mycelium which appear under the sideboards and in the manure at about the time of casing. Unlike the plaster mold, the truffles fungus Pseudobalsamia microspora Diehl and Lambert seems to stimulate rather than prevent the run of spawn in the early stages of the crop. A few weeks later, how-

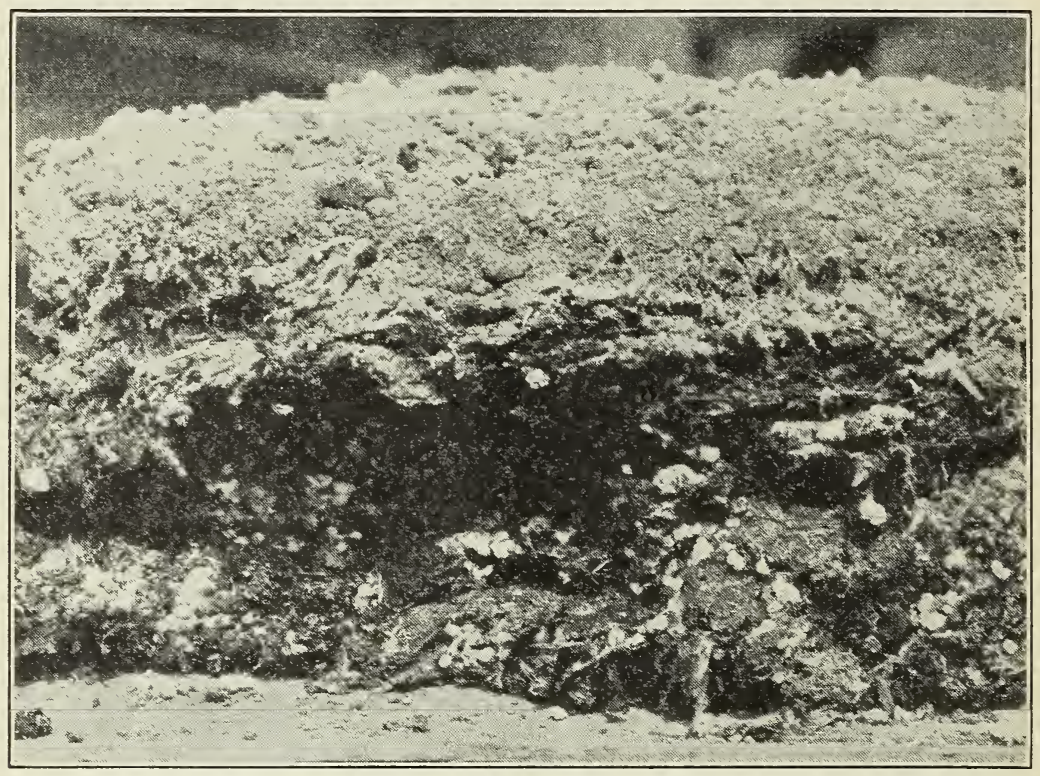

Figure 15.-Truffles disease in a mushroom bed

ever, when the truffles fungus matures and forms wrinkled fungus bodies in the manure and on the soil, the parts of the beds infested with truffles become barren and the mushroom mycelium almost completely disappears. (Fig. 15.) The source of this fungus is not known, since it has not yet been found outside of mushroom houses. However, the nature of the fungus and the history of the disease suggest that it lives in the soil and is carried into the house in the compost. There is also some evidence that it may remain from one crop to another in the bed boards and that high temperatures and an overwet condition of the manure favor its development. The spores are probably distributed principally at the time of emptying the beds.

It would seem advisable, if a house has been infested with truffles disease, to take the following precautions: Thoroughly fumigate 
the mushroom house with sulphur fumes or formaldehyde gas; disinfect the compost grounds by drenching with a solution of formaldehyde (1 pint of formalin to 15 gallons of water) or change the composting grounds; do not add soil to the manure or else change the source of soil; wet down the spent mushroom soil at the time of emptying to prevent the spread of spore dust; disinfect the truck used to haul spent soil; avoid storing the manure, early fall crops, running the spawn at high temperatures, and a wet, soggy condition of the compost during fermentation in the pile or in the house. In some cases soaking bed boards in disinfectant seems to have been beneficial. Until more is known about the source of the infestation and the conditions which favor it, all control measures must be considered tentative and no control program can be offered which will assure the eradication of the disease.

Another mold which sometimes penetrates deep into the beds is known to the growers as "olive mold." It belongs to the Chaetomium group and seems to be most serious in houses in which the manure has been overheated in the beds. An organism called "brown plaster mold "also is widespread, but it grows only under the side boards and on the surface of the bed and after some delay mushrooms push up through it.

\section{INSECT PESTS ${ }^{2}$}

The chief pests causing commercial damage to mushrooms are the fungus gnats, mites, and springtails.

In general, the fungus gnats of the genus Sciara cause the most injury to the mushroom industry. They are prevalent in almost every type of mushroom house or cave, since they usually enter in the compost when it is taken into the houses. The larvae or maggots of these flies cause injury both by destroying the mycelium in the beds and by feeding on the small mushrooms, which they completely devour in many instances. These maggots can also render the large mushrooms unfit for market by tunneling upward through the stem and cap. The adult flies often transport injurious mites which attach themselves to the bodies of the flies from one mushroom house to another and they also aid in disseminating some mushroom diseases.

The mites, while not generally so prevalent as the fungus gnats, are capable of causing serious losses once they become established in mushroom houses. The mushroom mite proper, Tyroglyphus lintneri Osb., feeds on the mushroom, producing dark pits which result in decay, destroys the mycelium in the beds, and cuts off the feeder root system so that the mushrooms do not mature, and decreased yields result.

It is much more widely distributed, apparently, than the mite, Linopodes antennaepes Banks, which has also been found causing commercial damage to mushrooms in sereral plants.

Springtails cause very little damage to mushrooms in the East, but are one of the most serious pests with which the growers operating in the sandstone caves of the Northwest have to contend. While the species found in the sandstone cares has never been described in the United States and apparently is not present in the East, it is doubtful

${ }^{2}$ Prepared by o. E. Gahm. formerly assistant entomologist, Bureau of Entomology, U. S. Department of Agriculture. 
whether it would cause a great amount of damage. in the modern eastern houses, since they provide atmospheric conditions unfavorable to the insects' rapid development and reproduction.

\section{PREVENTION AND CONTROL}

Because the mushroom mycelium, as well as the mushroom itself, is extremely sensitive to most fumigants, it is necessary to take certain precautionary measures before placing the spawn in the beds, in order to prevent heavy infestations by insect pests and subsequent damage.

In the course of the heat in the beds the temperature will rise high enough, if forced air circulation is employed, to either kill the insects in the compost or drive them to the surface where fumigants can be used effectively. Electric fans provide the necessary forced circulation of air during the heat.

Two 16-inch fans will equalize the air temperature all over the house and make the temperature in the compost fairly even in all the beds. The various pests can then be killed by fumigation while the temperatures are highest.

Calcium cyanide, scattered on the floor in the alleyways at the rate of 1 pound per 1,000 cubic feet of air space has heretofore been most widely used, but the burning of sulphur, which is cheap and has a double rôle as a fungicide and insecticide, is gradually replacing the use of cyanide. Burning sulphur at the rate of 2 pounds per 1,000 cubic feet of air space while the compost is at its greatest heat in the beds, and leaving the house closed for five hours after all the sulphur has burned, has proven very effective against any pests in the house at the time. Results of yield tests indicate that this process has not injured the compost for subsequent mushroom culture.

Results of hydrogen-ion determinations have shown conclusively that the sulphur fumes do not penetrate much more than 1 inch into the uncased compost and that the surface compost is rendered slightly more acid than it was before being fumigated. Hydrocyanic acid gas penetrates the compost to the same depth.

To prevent possible infestation of the houses after the compost has gone through its heat and has been fumigated, the doors and ventilators should be screened with 30 -mesh copper-wire cloth. To prevent rapid development and multiplication of insects and mites the temperature of the house should not go above $55^{\circ} \mathrm{F}$. while cropping.

A dust consisting of 60 per cent pyrethrum powder and 40 per cent finely ground clay, used at the rate of $21 / 2$ ounces per 1,000 cubic feet of air space, has proven very satisfactory for control of the adult flies and does not injure the mushrooms.

\section{HARVESTING, PACKING, AND MARKETING}

Comparatively little skill is required in picking mushrooms. They are usually gathered at a stage of growth about 12 hours before the veil would normally rupture. Mushrooms in the same stage of growth often range from 1 inch to 3 inches in diameter, so the principal consideration is not the size of the mushroom but whether it has finished growing in the closed form. Mushrooms are pulled rather 
than cut. After a mushroom or clump of mushrooms is picked, the fleshy stump is carefully remored and the hole is usually filled with fresh soil. The removal of these stumps is important, since their presence in the bed favors the development of green mold in the soil and the green mold prevents the formation of new mushrooms in the moldy areas. Large numbers of button mushrooms from one-eighth to three-eighths inch in diameter die off, even on normal beds, presumably because of the crowding out or breaking of the mycelial strands connecting the young mushrooms with their supply of nutrition in the compost. With a little practice these mushrooms are easily distinguished from healthy buttons and they should be removed from the bed for the same reason that the dead stumps are removed.

Most of the mushrooms sold in the United States are marketed fresh, although a well-established canning industry has developed

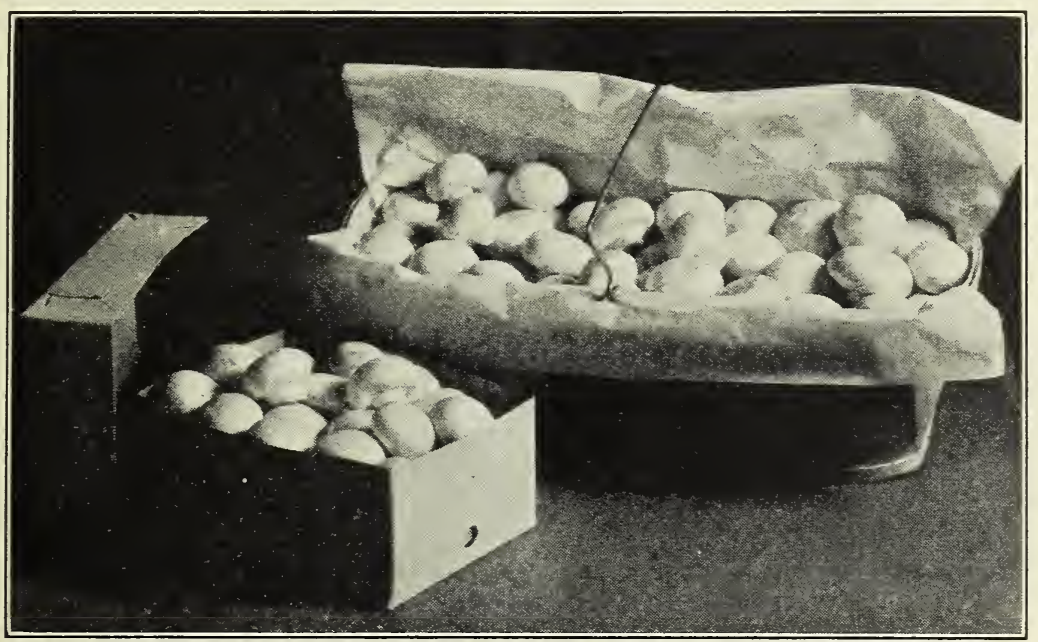

Figcre 16.-Mushrooms packed in the 1-pound paper carton preferred in the West and in the 3-pound baskets used in the East

in the last 15 years to take care of the demand for canned mushrooms. Fresh mushrooms are sold on the basis of weight, in the East in 3-pound baskets and in the West largely in 1-pound paper cartons. (Fig. 16.) When packed fresh they are usually sorted according to varietal characteristics, size, and freedom from blemishes. In most large cities they are sold on a commission basis through produce dealers. In smaller cities they are sometimes shipped directly from the grower to hotels. Shipment from surrounding States into Chicago is usually made by express, whereas nearly all of the mushrooms shipped from Pennsylvania into New York City are taken directly from the grower to the commission dealer in automobile trucks.

Often both the grower and the consignee benefit from the use of United States standards for mushrooms when handling the best grade. Mushrooms may be graded and the containers marked United States No. 1 provided they contain good quality mushrooms larger than 
1 inch in diameter. They may be marked United States Small, United States Medium, United States Large, and United States Extra Large if they conform to the quality requirements under United States No. 1 and the following size specifications: Small, under 1 inch in diameter; medium, 1 to $15 / 8$ inches; large, $15 / 8$ to 3 inches; extra large, over 3 inches. Packages in any of these grades should contain fresh mushrooms of similar varietal characteristics which are not badly misshapen, are free from disease, insect injury, open cap, spots, and damage caused by dirt, or by mechanical or other means, and having stems properly trimmed and not more than $11 / 4$ inches long. ${ }^{3}$

Mushrooms are canned in Pennsylvania, Delaware, Ohio, Minnesota, and Colorado. Usually they are received at the cannery and processed on the day they are picked. Button mushrooms are preferred for canning. These are sorted out on a moving belt, carried immediately to vats where they are preheated until they have shrunk about 40 to 50 per cent in bulk, placed in cans, weighed, and processed.

A few growers have tried marketing dried mushrooms, but this product has not seemed to find much favor with the consumer and must meet the competition offered by dried mushrooms from the Orient and southern Europe.

\section{COSTS AND RETURNS}

Mushroom growers must meet many of the same economic difficulties that confront the producers of other perishable crops. The cost of production is difficult to predict and the sale price is almost entirely out of the grower's control. Although the cost of raising a crop is largely fixed, the cost of producing a pound of mushrooms often varies considerably from one crop to another, depending on the yield per square foot of bed space. The price differs from one locality to another and from one season to another. In the East prices are usually somewhat higher during the summer than in the winter, because fewer mushrooms are grown in the summer. Warm spells in the early fall and late spring may greatly increase the supply of mushrooms for several days at a time by raising the temperature in mushroom houses. The temperature rise is reflected in an increased rate of growth of the mushrooms and in the production of a larger proportion of buttons. In congested centers of mushroom growing this usually occurs in hundreds of mushroom houses at the same time and the grower often finds himself in the untenable position of producing the most mushrooms when the price is below the cost of production.

If a yield of 1 pound per square foot is assumed, the cost of producing mushrooms in eastern Pennsylvania in 1930 was about 26 cents a pound. This may be divided as follows: Interest on investment, depreciation, and upkeep of buildings, 5 cents; raw materials, 14 cents; and labor, 7 cents. (Table 1.) The estimated cost of manure may differ as much as 3 or 4 cents from one locality to another; the

3 Copies of the latest United States specifications for mushroom grades and sizes, including the definition of terms and the percentage of tolerance of off types, can be obtained on request from the Bureau of Agricultural Economies, U. S. Department of Agriculture, Washington, D. C. 
interest and depreciation charge may be reduced when abandoned buildings or caves are used; and labor cost will vary in different localities and in different years. Otherwise costs are fairly comparable in different localities. In some localities spent manure or "mushroom soil " is sold to truck gardeners, but this rarely returns an income of more than enough to pay for hauling it away.

TABLE 1.-Estimated cost of raising mushrooms in Chcster County, Pa., 1930

\begin{tabular}{|c|c|c|}
\hline \multirow{2}{*}{ Item } & \multicolumn{2}{|c|}{$\begin{array}{l}\text { Cost per pound of } \\
\text { mushrooms when } \\
\text { yield is- }\end{array}$} \\
\hline & $\begin{array}{l}1 \text { pound } \\
\text { per square } \\
\text { foot }\end{array}$ & $\begin{array}{l}11 / 2 \text { pounds } \\
\text { per square } \\
\text { foot }\end{array}$ \\
\hline $\begin{array}{l}\text { Interest on investment }(6 \text { per cent of } \$ 5,000=\$ 300) \\
\text { Depreciation }(5 \text { per cent) } \\
\text { Manure, at } \$ 5.25 \text { per ton (for } 70 \text { square feet of bed space) } \\
\text { Freight on manure, at } \$ 1.25 \text { per ton } \\
\text { Hauling manure to house, at } 60 \text { cents per ton } \\
\text { Composting manure, three turns } \\
\text { Filling house } \\
\text { Emptying house } \\
\text { Fumigating and disinfecting } \\
\text { Heat and light } \\
\text { Spawn and planting } \\
\text { Venting } \\
\text { Picking and cleaning beds, watering, and miscellaneous } \\
\text { Packing } \\
\text { Baskets, wire, and paper, at } 5 \text { cents per basket }\end{array}$ & $\begin{array}{r}\$ 0.0214 \\
.0178 \\
.0750 \\
.0178 \\
.0085 \\
.0081 \\
.0063 \\
.0060 \\
.0036 \\
.0113 \\
.0200 \\
.0040 \\
.0050 \\
.0266 \\
.0116 \\
.0166\end{array}$ & $\begin{array}{r}\$ 0.0143 \\
.0119 \\
.0500 \\
.0119 \\
.0057 \\
.0054 \\
.0042 \\
.0040 \\
.0024 \\
.0075 \\
.0133 \\
.0027 \\
.0033 \\
.0222 \\
.0116 \\
.0166\end{array}$ \\
\hline Total & .2596 & .1870 \\
\hline
\end{tabular}

The following cost information, based on the estimates (made in 1930) of several commercial growers, was used in calculating the detailed costs per square foot of bed space shown in Table 1.

Cost of building a double house (approximately 14,000 square feet) in a row of 10 is estimated at $\$ 4,000$ on a basis of wood construction, 100 feet long, 6-foot beds six high, including heating plant. Equipment for this unit, including trucks, is estimated at $\$ 1,000$.

Cost of composting manure is based on the turning and watering of a 90 -ton heap three times by hand labor with six men in 27 hours, at 35 cents per hour. (A heap of this size fills a 7,000-square-foot house.)

Filling a house of 7,000 square feet, by hand labor, takes seren men 18 hours (at 35 cents per hour), and costs $\$ 44.10$.

Emptying a house of 7,000 square feet takes six men 20 hours (at 35 cents per hour) and costs $\$ 42$.

The cost of fumigating a house of 7,000 square feet is estimated at $\$ 25$ for sulphur, pyrethrum, labor, etc.

The cost of heat and light is estimated at $\$ 80$ for 7,000 square feet, using soft coal.

Spawning and planting cost is based on the use of one bottle of spawn, costing 70 cents, for 35 square feet.

The cost of casing 7,000 square feet with soil from land belonging to grower includes that of screening (requiring 20 man-hours at 35 cents per hour) and hauling and casing (requiring five men 12 hours), and totals $\$ 28$.

The cost of picking and cleaning beds is based on one man picking four to six baskets per hour, at 40 cents per hour (including cleaning the beds).

Ventilating, watering, and miscellaneous costs are estimated at \$35 for each 7,000 square feet.

Packing cost is estimated on the basis of 10 baskets per man-hour, at 35 cents. 
Except in isolated cities where one or two growers control the supply, mushrooms are sold on consignment and the price received for them is based on the prevailing values, as indicated by sales from receivers and wholesalers or retailers. In New York and Chicago the receiver charges a commission of 10 per cent for handling mushrooms. The white variety commands a better price than cream or brown and large mushrooms bring a higher price than buttons. The daily fluctuations in supply and price and the premiums paid for the different classes of mushrooms on the New York market are shown in Figure 17. On this market a higher average price is maintained in the summer because of the greatly reduced supply. (Fig. 18.) This figure also illustrates the response of the market

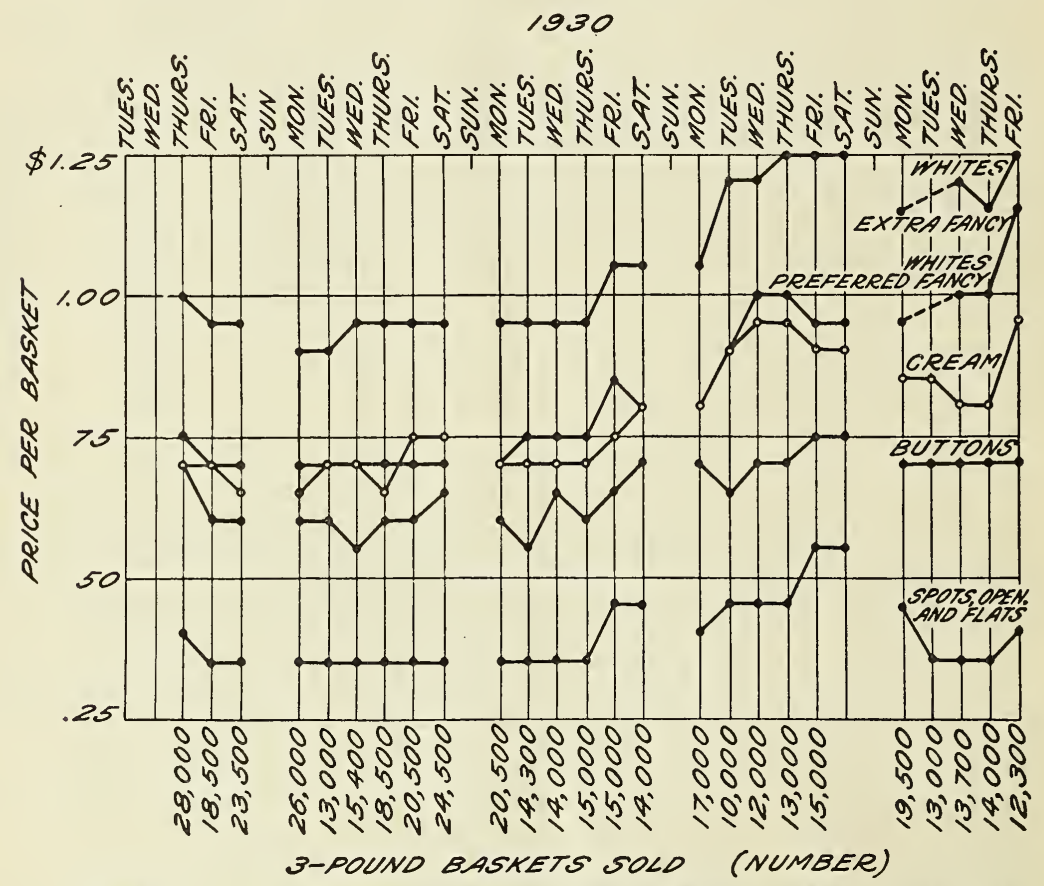

FIGURE 17.- The daily fluctuation in the price of different grades of mushrooms quoted on the New York market, January, 1930

to holidays and shows that the market is much more sensitive to small changes in supply during the summer, when the supply is low and the price comparatively high. On the Chicago inarket prices are slightly higher in the winter but rarely reach the peak summer prices that prevail on the New York market.

Canners specialize in high-quality button mushrooms and often fix a purchasing price in the fall that remains fairly constant throughout the winter.

The foregoing data indicate clearly the necessity for locating mushroom establishments near a good market and near an adequate and cheap source of manure and suitable casing soil. They also show that high yields and high quality of product should be the paramount considerations. Savings derived from the use of mechanical 


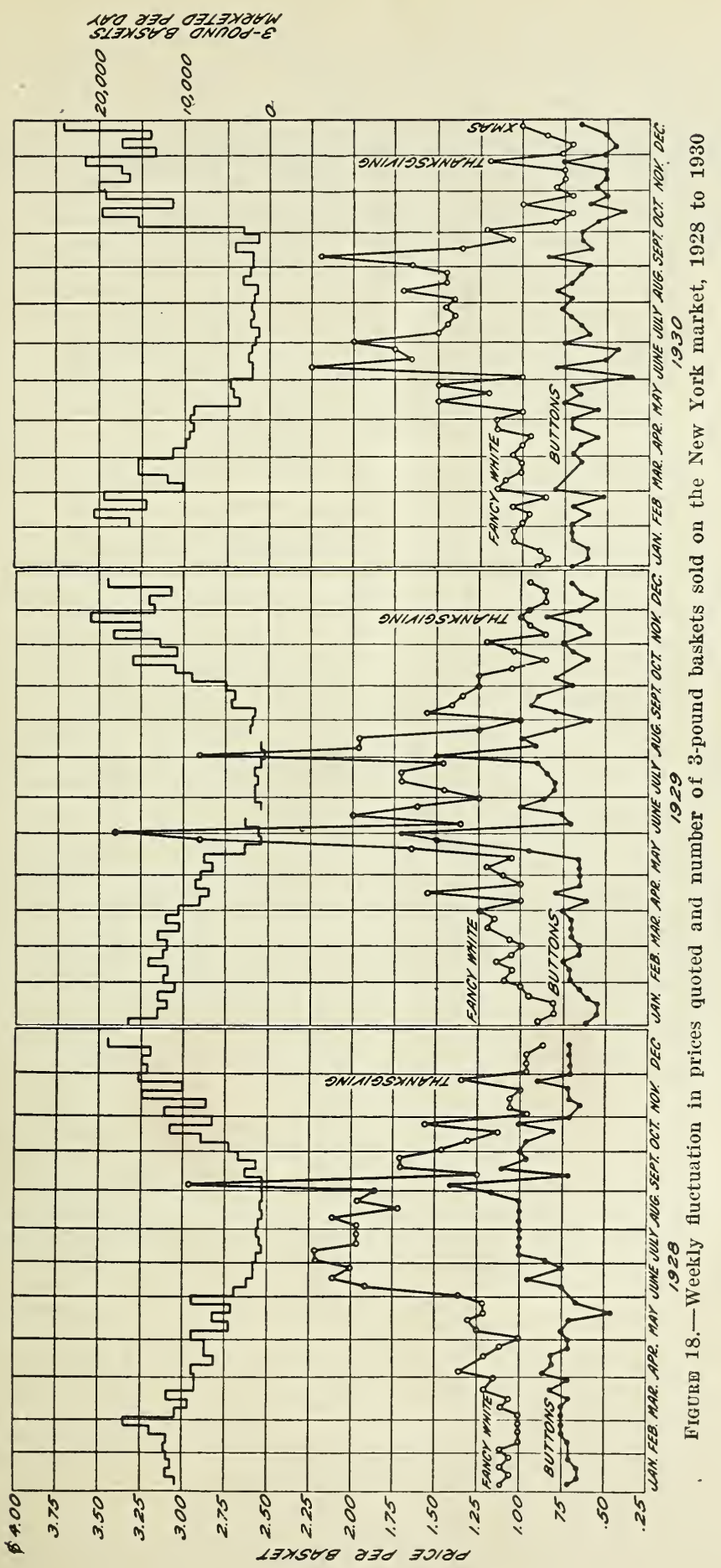


means of turning the manure and filling the houses are evidently too small to give the large-scale producer much advantage over the smaller grower who is able to maintain a high average yield by personal attention to essential details. On the other hand, it is apparent that a mushroom plant must have 40,000 to 50,000 square feet of bed surface before wages of management can be expected even by an experienced grower. Under conditions prevailing in 1930 a plant of this size represented an investment of from $\$ 15,000$ to $\$ 20,000$. 


\section{ORGANIZATION OF THE UNITED STATES DEPARTMENT OF AGRICULTURE WHEN THIS PUBLICATION WAS LAST PRINTED}

Secretary of Agriculture Assistant Secretary

Director of Scientific Work

Director of Regulatory Work.

Director of Extension Work

Director of Personnel and Business. Administration.

Director of Information Solicitor.

Bureau of Agricultural Eeonomies

Bureau of Agricultural Engineering

Bureau of Animal Industry

Bureau of Biological Survey

Bureau of Chemistry and Soils

Office of Cooperative Extension Work

Bureau of Dairy Industry.

Bureau of Entomology

Office of Experiment Stations

Food and Drug Administration

Forest Service

Grain Futures Administration

Bureau of Home Economics.

Library

Bureau of Plant Industry

Bureau of Plant Quarantine

Bureau of Public Roads

Weather Bureau
ARThur M. Hyde.

R. W. Dunlap.

A. F. Woods.

WAlter G. CAMPBell.

C. IV. WARBURton.

W. W. Stock berger.

M. S. EISENHOWER.

E. L. Marshall.

Nils A. Olsen, Chief.

S. H. McCrory, Chief.

John R. MoHLer, Chief.

Paul G. Redington, Chief.

H. G. KNight, Chief.

C. B. Sмith, Chief.

O. E. ReEd, Chief.

C. L. Marlatt, Chief.

James T. Jardine, Chief.

Walter G. Campbeld, Director of

Regulatory Work, in Charge.

R. Y. Stuart, Chief.

J. W. T. Duvel, Chief.

Louise Stanley, Chief.

Claribel R. Barnett, Librarian. William A. Taylor, Chief.

Lee A. Strong, Chief.

Thomas H. MacDonald, Chief. Charles F. Marvin, Chief.

This circular is a contribution from

Bureau of Plant Industry

Division of Mycology and Disease Survey
William A. TaYlor, Chief. C. L. Shear. Principal Pathologist, in Charge.

35 
